\title{
Ordu Mesudiye Köykent Projesinde Katılım ve Bunun Bireysel Sosyoekonomik Özelliklerle ilişkisi: Kırsal Kalkınma için Çıkarımlar ${ }^{1}$
}

\section{Participation in the Ordu-Mesudiye Village-Town Project and Its Relations to Individuals' Socio-economical Characteristics: Implications for Rural Development}

\author{
Prof. Dr. Mehmet C. Marın²
}

Başvuru Tarihi: 24.04.2019

Kabul Tarihi: 28.04.2020

Makale Türü: Araştırma Makalesi

Öz

Bu çalışma Ordu, Mesudiye Köykent Projesi sürecindeki katılımın niteliği ile bireylerin sosyoekonomik ve demografik özelliklerinin katılımın düzeyine etkisini 149 hane reisine uygulanan bir anketin verileri ve siral logit modeline dayanarak incelemektedir. Bulgular, katılımın proje resmî belgelerinde ve bazı çalışmalardaki iddiaların aksine sınırlı düzeyde kaldığını, özellikle kadın ve yoksulları yeterince kapsamadığını göstermektedir. Bulgulara göre, hane halkı reislerinin katılım düzeyleri, yaş, cinsiyet, eğitim, kooperatif üyeliği, toprak mülkiyeti ve gelire bağlı olarak değişmektedir. Yapılan faaliyet türü ve köyde geçirilen sürenin ise katılım üzerinde anlamlı etkileri bulunmamaktadır. Katılım ile proje sonuçlarının benimsenme düzeyleri arasında da anlamlı bir korelasyonun bulunmuştur. Sonuç olarak bulgular, katılımın kırsal kalkınma girişimlerinin meşruiyeti ve sürdürülebilirliğini sağlama ve daha başlangıç aşamasında dikkatlice planlamasının önemini göstermektedir.

Anahtar Kelimeler: Köykent, Katılım, Kalkınma, Sosyoekonomik Özellikler

\begin{abstract}
This study analyzes characteristics of participation and effects of individuals' socioeconomic and demographic features on their participation levels in Mesudiye, Ordu, Village-Town Project, based on a logit model and the data from a survey conducted among 149 households' heads. The findings show that participation was relatively limited; contrasting with the claims of project's documents and some studies, and did not adequately represent the women and the poor. While participation varied depending on age, gender, education, cooperative membership, land

\footnotetext{
${ }^{1}$ Bu makalede kullanılan veriler, TÜBİTAK SOBAG tarafından desteklenen 107K152 nolu ve "Ordu-Mesudiye Köykent Projesinin Katılım, Mekânsal ve Sosyoekonomik Boyutlarıyla Bir Değerlendirmesi” adlı projeden gelmektedir. Destekleri için kendilerine çok teşekkür ederim.

2 Hakkâri Üniversitesi, İktisadi ve İdari Bilimler Fakültesi, mcmarin@hakkari.edu.tr, ORCID: 0000-0002-2022-3952
} 
ownership, and income, type of activity and time stayed in villages did not have any effect. In addition, individuals' participation was correlated with their perception of project efficiency. In general, the findings indicate the importance of participation both for ensuring legitimacy and sustainability of any development initiative and its need for a careful planning.

Keywords: Village-Town, Participation, Development, Socioeconomic Characteristics

\section{Giriş}

Gelir artı̧ı, teknoloji transferi, verimlilik ve fiziksel altyapı yatırımları gibi olgulara odaklanan modernleşmeci kalkınma anlayışından yerel özgünlükleri ve insanı merkezine alan bir anlayışa geçiş, yerel düzeydeki koşullar, bilgi, beceri ve sosyal ilişkiler gibi topluluk özelliklerine eğilmeyi zorunlu kılar. Toplulukların kendilerini doğrudan etkileyen kalkınma sorunlarına etkin çözümler üretilebilmeleri için sahip oldukları maddi kaynak, bilgi, beceri ve genel olarak tüm çabalarını harekete geçirebilmeleri gerekir. Bunun için de birey olarak yaşamlarını yakından etkileyen koşullar ve faaliyetlere müdahale edebilmeleri ve buna ilişkin kararlara aktif katılımlarıyla mümkün olabilir.

2000 ylında başlatılıp 2002 yllında tamamlanmadan sona erdirilen Ordu Mesudiye'deki Çavdar Merkezli Köykent projesinin ilgili resmî belgeleri ve bilimsel çalı̧̧alarda önceki kırsal kalkınma anlayışlılarından katılımcılık yönü ile farklı olduğu özellikle vurgulanır. Köykent projesinin Mesudiye'de uygulanmasının gerekçesinde ise yöredeki güçlü demokratik ve katılımcı kültüre sahip nüfus ile 1991'den beri her yl düzenli bir şekilde toplanmakta olan Mesudiye İlçe Kurultayının varlığına dikkat çekilir (Bkz.MEGEV; 2003; Başa, 2000 ve 2007; Erdönmez, 2005; Yıldız, Güler ve Başa, 2009; Kovanc1, 2005). Mesudiye Dernekler Federasyonu'nun (MESDEF) bugün için sayıları kırkı aşan üyesi de yörede gerecekten de güçlü bir örgütlenme geleneğinin bulunduğunu göstermektedir.

Yerel halkın katılımcllığına ve tabandan tavana bir anlayışa dayandığı iddia edilen Köykent (Başa 2000) gibi projelerin başarılı sonuçlar doğurması için, bireylerin örgütlenme ve katılımcı davranış özellikleri göstermeleri önem taşımakla birlikte tek başına yeterli olmayabilir. Üstelik halkın kırsal kalkınmaya dahil edilmesi demek, her kararın halkın erişimine ve etkisine açı olduğu anlamına da gelmez (Cornwall, 2008, s. 280). Ayrıca birçok açıdan olumluluk içeren anlamına rağmen, katılımcı yaklaşımlar uzman, bürokrat veya güçlünün elinde çok farklı amaçlar için de kullanılabilmektedir (Cooke, 2004, s. 46-47; Oakley, 1991, s. 118). Bundan dolayı da Oakley (1991, s. 117) arzulanan birtakım sonuçlar doğurması beklenen katılımın, doğasını tanımlamak gerektiğine dikkat çeker.

$\mathrm{Bu}$ çalı̧̧mada temelde iki soruya yanıt aranmaktadır. Birincisi Ordu, Mesudiye Köykent projesinin planlaması, uygulanması ve değerlendirmesi aşamalarına halkın ne ölçüde katılım sergilediği ve bu anlamda resmî belge ve bazı çalışmalarda iddia edildiği gibi katılımcı bir proje olarak değerlendirilip değerlendirilemeyeceğini belirlemektir. İkincisi ise proje alanında yaşayan hane halkı reislerinin katılım düzeylerini etkileyen bireysel sosyoekonomik ve 
demografik özellikleri belirlenmektir. Bu çalışmadan elde edilecek bulguların kırsal kalkınmaya katılım ve katılımın planlanmasına ilişkin Türkiye'deki çalışmalara, kırsal kalkınma kapsamında yaşama geçirilecek projelerin katılım açısından daha iyi planlanması ve tasarlanmasına katkı sağlaması umut edilmektedir.

\section{Kavramsal Çerçeve}

$\mathrm{Bu}$ çalışma kapsamında kırsal kalkınma projelerine katılım, proje sonuçlarından etkilenebilecek tüm kesimlerin projenin yaşam döngüsünü meydana getiren planlama, uygulama ve değerlendirme aşamalarına bilgi, işgücü, mali ve diğer tüm kaynaklarıyla katkı sağlayabilme ve özellikle bu aşamalarda alınan kararları etkileyebilme olanaklarının olması olarak tanımlanmaktadır.

Bir çalışmanın da dikkat çektiği gibi, eğer katılım literatürde tartışıldı̆̆ kadar yararlı ise, neden herkesin katılım göstermediği (Wandersman ve Giamartino, 1980, s. 218) sorusu bir açıklama gerektirmektedir. Nitekim gerçek yaşamda da firsatları olduğu halde çok az sayıda kişinin katılım göstermesi de bütün suçu planlamacı ya da proje yönetimine atmanın yanlı̧ olacağını gösterir. Belki de bu durum, aynı topluluktan gelen ve benzer koşullara sahip kişilerden katılım sergileyenleri sergilemeyenlerden ayıran bazı bireysel sosyoekonomik ve demografik özellikler ya da kişisel güdülerinin farklllığıyla açıklanabileceğinin bir göstergesi de olabilir. Örneğin Wynn, Crabtree ve Potts. (2001, s. 68), bir kırsal kalkınma programına katılımı etkileyebilen faktörleri, işletmenin fiziksel özellikleri, çiftçi özellikleri, iş koşulları ve durumsal etkenler olarak dört gruba ayırırlar. Siyasal katılım literatüründe de kişisel özellikler katılımcllığı etkileyen temel faktörler olarak belirir. Buna karşılık katılım koşulları ve kurumsal yapılar gibi bağlamsal etkenler, ikincil faktör olarak ortaya çıkar. Bu nedenle de siyasal katılımın açıklanması için bireysel sosyoekonomik ve demografik özelliklere dayanan ve SES modelleri olarak bilinen yaklaşım genelde kabul görmektedir (Leighley, 1995, s. 185-186). Kişilerin sahip oldukları yaş, cinsiyet, eğitim, bilgi ve beceri gibi özellikler, beşerî sermayeyi oluşturmaktadır. Bir anlamda bireysel sosyoekonomik ve demografik özellikler, tüm davranışların kaynakları olarak değerlendirebilir. Bunlar genel olarak davranışları ve dolayısıyla katılımı, teşvik edebilir ya da sınırlandırabilir. Örneğin kırsal alanlardaki genç çiftçilerin yeni programları benimseme düzeyleri daha yüksektir (Wilson, 1996; Dupraz, Vanslembrouck, Bonnieux, ve van Huylenbroeck, 2002). Yine kişilerin gelirleri, maddi ve manevi varlıkları hem toplumsal konumun belirlenmesindeki rolleri hem de kişisel yapabilirlikler seçeneklerini etkileme yoluyla katılımı şekillendirebilir.

Toplum üyeleri arasında karşılıklı güven ve iş birliğinin ortaya çıması, müzakerelerin teşvik edilmesi ve farklı etkinliklerin eşgüdümündeki rolü ve genel olarak karşılıklı ilişkilerde izlenecek kuralları belirleyen sosyal sermaye, toplumsal işlem maliyetlerini azaltırken katılımın koşulları ile bunlara ilişkin algıları da etkiler. Sosyal sermaye, topluluk üyelerinin karşılıklı güvenleri, destekleyici ilişkileri ve bunların sosyal ağlarının gelişmesi ve sürdürülmesine ilişkin topluluğa içkin formel ve enformel kurallar bütünüdür. Chaudhuri ve Heller (2003, s. 7-25) oynanmakta olan bir oyunun kuralları olarak gördüğü kurumları ve sosyal yapıları, bireylerin seçenek setlerini, fırsat ve maliyetlerini farklı şekillerde etkileyebileceğine dikkat çeker. Kurallar, 
normlar ve algılar başta kadınlar ve yoksullar olmak üzere belirli kesimler için çoğu kez dezavantajlar yaratabilir. Claridge (2004, s. 28) birçok toplumda erkek ve kadınların algıları, ihtiyaçları ve karşı karşıya oldukları fırsatların, farklılık gösterdiğini belirtir. Bunlar dezavantajlı kesimlerin kalkınma programlarına katılımlarını sınırlandırabilir. Diğer taraftan kurallar da toplumdaki güç ilişkilerince şekillenir. La Ferrara (2002), topluluk içindeki gelir dengesizliğinin artışının, grupların kompozisyonu ve genel katılım üzerinde net olmayan etkilere sahip olduğunu, katılımın toplumsal gelir dağılımının şekli ve erişim kurallarına bağlı olduğuna dikkat çeker.

Rasyonel Seçim Teorisi, katlımın hem fayda hem de maliyetlerinin olduğunu belirtir. Maliyet ve faydalar doğrudan ve dolaylı olabilirler. Maliyetler, yapılan maddi masraflar, zaman ve firsat maliyetlerinden oluşur (Chaudhuri ve Heller, 2003, s. 7). Her davranış gibi katılım da daha çok kalkınma projelerinin sağlayacağı imkânlarından yararlanma güdüsü ile gerçekleşmektedir (Jones ve Kardan, 2013; Rono ve Aboud, 2003). Örneğin bir çalışmada kırsal turizme açabilecekleri mülkleri olanların, kişisel gelir beklentisiyle ve doğrudan yarar sağlayan projelere daha çok katılım sergiledikleri belirlenmiştir (Ertuna, Güney, Güven ve Aydemir, 2012, s. 61). Diğer taraftan rasyonel seçim teorisi, katılım maliyetlerinin faydalarından daha yüksek olduğu durumlarda katılımın gerçekleşmeyebileceğine de dikkat çeker.

Yukarıdaki tartışmalar aktörlerin güdüleri ile katılım koşullarını anlamanın önemini de göstermektedir. Çok sayıda ve farklı psikolojik güdüler katılımı etkileyebilmektedir (Swapan 2016, s. 70; Wandersman vd., 1980, s. 218; Ohmer, 2010, s. 7). Bunlar bireysel kazançlardan (Jones vd, 2013: 10; Ertuna vd., 2012: 64) ya da mensubu olduğu topluluğun gelişmesine katkı sağlama sorumluğunu duyma gibi değerlerden topluluk işlerine katılıma ilişkin inanç ve tutumlara varıncaya kadar değişebilmektedir. Mathies ve Krömker (2000, s. 65) katılımcı planlamaya ilişkin birçok çalışma örneği sunarak bireysel özellikler ve kişisel psikolojik durumlar gibi müdahalenin yapıldığı koşulların, programların sonuçlarını etkilediğini gösterir. Arnstein (1969, s. 216) de katılımın şekli ile bireylerin kararları etkileyebilme gücüne inancı arasında yakın bir ilişki kurar. Swapan $(2016$, s. 70) da bazı yapılar ve katılım sürecinin kendisinin amaçlar için elverişsiz olması ya da katılımcıların özellikleriyle uyumsuzluk göstermesinin, katılımı olumsuz etkilediğine dikkat çeker. Katılım programının tasarımına gerekli özenin gösterilmemesi, katılımın konusu, amaç ve teknikleri arasında uyumsuzluğa yol açar (Glass, 1979).

\section{Konuya İlişkin Önceki Çalışmalar}

Katılımın gerekçeleri, sağlayabileceği faydalar ile bunların en iyi bir şekilde nasıl gerçekleştirilebileceğine dair tartışmalar, konuya ilişkin literatürde önemli bir yer tutarken kavrama yönelik eleştiriler de göze çarpmaktadır. Participation: The New Tyranny (Cooke ve Kothari, 2001) gibi kitaplar, genelde olumlu bir mana yüklenen katılımın esasında anlam olarak oldukça bulanık olduğunu ve bazı gizli hedeflere ulaşmak için bir araç olarak kullanılabileceğine ilişkin eleştirilerle doludur. Nitekim katılımın siyasal bir olgu olarak görülmesi gerektiğine dikkat çeken White, kavramın egemen tahakkümcü güç şekilleriyle mücadele etmede 
kullanılabilme potansiyeline rağmen, mevcut güç ilişkilerinin genişletilmesi ve yeniden üretilmesinin aracı da olabileceğini belirtir (White, 1996, s. 6).

Katılımın hemen hemen tüm alanlarda tartışılan önemli bir konu olması, çok farklı perspektiflerden değerlendirilen oldukça geniş, kapsamlı ve zengin bir alanyazınının ortaya çıkmasına yol açmıştır. Ancak bu araştırmanın sorularının yanı sıra, zaman ve yer darlığının dayattı̆̆ı sınırlandırmalar, daha çok kırsal kalkınmaya katılıma ilişkin alanyazının ve bunun da kısmen gözden geçirilebilmesine olanak sağlamaktadır.

Kırsal kalkınmada katılımın popüler hale gelmesinde, geçmiş kalkınma girişimlerinin başarısızlığı, kaynakların yanlış kullanılması ve yerel toplulukların geçmiş kalkınma çabalarına ilişkin yaşadıkları hayal kırıklıklarının rolü bulunmaktadır (Claridge, 2004, s. 22). Katılım 1970'lerde dünya yoksullarının önemli bir kısmının kalkınma sonuçlarından olumsuz etkilendiği ve herkesin kalkınma kararları, bunların yaşama geçirilmesi ve ortaya çıkan faydalarından yararlanması gerektiğinin anlaşılmasıyla önem kazandı. Bu arada katılımcı yaklaşımlar geliştikçe, geleneksel indirgemeci yukarıdan aşağıya yaklaşımlara içkin zayıllıklar da ortaya çıtı (Claridge, 2004, s. 17). 1979'da Roma'da toplanan Dünya Kırsal Kalkınma ve Tarımsal Reform Konferansinda, kalkınma programlarının tasarım ve uygulamalarına yoksul kesimlerin katılımlarının sağlanamadığı ve bunun da söz konusu girişimlerin başarısızlıklarının temel nedenlerinden birisi olduğu bildiriliyordu. Konferansta ayrıca dezavantajlı kırsal kesimlerin örgütlenme ihtiyacı vurgulanmış, sosyal ve ekonomik kurumları kontrol etmelerinin önemine dikkat çekilmiştir (Özer, 2004, s. 17-18). Nitekim 1960 ve 70’lerde katılımı savunanların dayandıkları bir gerekçe de insanların kendi yaşamlarını etkileyen kırsal kalkınma projelerine doğrudan katılımlarının, başarı şansını da artıracağıydı. Bu görüş 1970'lerde Dünya Bankasınca da etkinlik ve verimlilik artışı ve proje yararlarının eşit paylaşımı temelinde desteklendi (Cornwal, 2000, s. 20). 1993 tarihli İnsan Gelişimi Raporu, katılımı kaçınılmaz ve yaşamın bir koşullu olarak ve genel bir kalkınma stratejisi olarak görmektedir. Bu strateji, insanların birçok firsatlara erişimini sağlayabilen liberalleşme, örgütlenme özgürlüğü ve demokratik yönetim kavramlarını ayırt edilemez şekille birbirine bağlamaktadır (Cornwall, 2000, s. 31-32). Arnstein (1969, s. 216) de katılımı, yönetilenlerin kendi yönetimlerine katılımları ve teorik olarak demokrasinin köşe taşlarından birisi olarak değerlendirir.

Ülkemizde kırsal kalkınma projeleri, Dünya Bankası gibi uluslararası kuruluşlarca dışardan sağlanan finansal desteklerle başlatılmış ve geleneksel olarak merkezden aşağıya bir yaklaşımla yönetilmiştir. Zaman zaman resmî belgelerde kırsal kalkınma sürecinde katılımın önemi vurgulanmış olsa da uygulamada uzmanlık bilgisi ve teknik çözümlere olan güçlü inanç ve mevcut kurumsal ve toplumsal kültür, gerçek anlamda işleyen bir katılıma izin vermemiştir. Nitekim Tekeli (2009) de ülkemizdeki planlamaciların katılıma genel olarak olumlu bir yarg1 yüklemeleri ve gerçekleştirilmesinin gereğine inanmalarına rağmen, bunun uygulamaya geçmediğini ve her kişinin katılımdan farklı bir anlam çıkardığına dikkat çeker (s. 180). Türkiye'deki şehir ve bölge plancılarının katılıma olan yaklaşımları için bu söylenenlerin genel olarak kırsal planlama ve kalkınma çalışmalarında rol alan bürokrat ve uzmanların anlayışlarını da yansıttığı iddia edilebilir. 
AB'nin aday statüsünün kazanılmasından sonra, Türkiye'de daha önce merkezce hazırlanan ve yukarından aşağıya bir yaklaşıma dayanan kalkınma program veya politikaları yerine yereldeki aktörleri önceleyen, kaynakların niteliklerini dikkate alan ve bunları harekete geçirmeyi amaçlayan aşağıdan yukarıya yaklaşımlar önem kazandı (Işıkçı, 2018, s. 419). Türkiye'de kırsal kalkınma yaklaşımları, dünya genelinde 1980 sonrası küreselleşme ve neoliberal ekonomik politikaların yaygınlaşması gibi genel olarak dünya ekonomisindeki yapısal dönüşümler (Tutar ve Demiral, 2007, s 72) ile IMF, Dünya Bankası, Dünya Ticaret Örgütü, OECD ve Avrupa Birliği' nin (AB) etkisi altında şekillendi. Tam adaylık üyeliğimizin kabul edildiği 1999 tarihli Helsinki Zirvesi ardında ise AB tarım, bölgesel ve kırsal kalkınma politikalarımızda en önemli aktör haline geldi. Katılım ortaklı̆̆ belgelerinde de dile getirilen talepler doğrultusunda 2002 yılında AB'dekine benzeri üç düzeyli İstatistiki Bölge Birimleri (NUTS) oluşturuldu. 2006' da ise AB'nin mali desteklerinden de yararlanmak üzere NUTS 2 düzeyinde 26 adet bölgesel kalkınma ajansın kurulmasının yasal dayanağını oluşturan 5449 sayılı Kalkınma Ajanslarının Kuruluşu, Koordinasyonu ve Görevleri Hakkında Kanun yürürlüğe girdi (Işıç̧, 2018, s. 422423; Tutar vd., 2007, s. 71-72; Cankorkmaz, 2011, s. 125).

Yerel kaynakların yerinde ve etkin kullanımı yoluyla ekonomik kalkınmayı destekleyen Bölgesel Kalkınma Ajansları (BKA), bölgedeki aktörler (kamu, özel ve sivil toplum kuruluşları) arasında iş birliği ve ağsal ilişkiler geliştirme ve böylece farklı yerel çıkarların ortaklaştırmasına yönelik kapasite geliştirme ve öğrenmeyi teşvik etmenin yanı sıra tavsiyeler yapma gibi yumuşak siyasal araçlara başvuran kurumlardır (Güney ve Sat, 2016, s. 102). BKA'ların üç ilkeye göre örgütlenmeleri gerektiği iddia edilmektedir. Birincisi BKA'nın merkezin sadece genel düzeyde ve çok az yönlendirdiği aşağıdan yukarıya doğru örgütlenen bir modele dayanması gerektiğidir. Bu modelin yerelin özgün koşulları ve sorunların çözümü için daha esnek ve elverişli olduğu düşünülmektedir. Böylece yerel aktörler kendi koşullarıyla da uyumlu daha esnek politikalar geliştirebilirler. İkinci ilkeye göre, BKA' lar yerel kapasite ve aktörlerin güçlerine dayanan stratejik bölgesel plan veya programlar geliştirerek uygulamalıdır. Son olarak BKA'ların karar alma sürecinin hiyerarşik bir yapı yerine eşitler arasındaki ilişkiye dayanan, müzakere ve uzlaşmaya olanak sağlayan bir yapıda olması gerektiğidir. Sonuç olarak BKA'lar bölgesel kalkınmayla ilgili karar verme, politika üretme ve uygulamalarda bölgede yaşayan farklı kesimlerin aktif bir şekilde rol almalarını sağlayan yönetişim ve tasarım kurumlarıdır. Böylece eskiden sadece devletin üstlendiği kalkınma misyonu, yereldeki potansiyel kaynakları harekete geçiren toplumun farklı kesimleri arasında da paylaşılabilmektedir (Güney vd, 2016, s. 102103). "Yerele özgü" kavramı, fiziksel, ekonomik, sosyal ve siyasal koşulların bir bölgeden diğerine değiştiğini ve dolayısıyla ancak aktörlerin bir müzakere sürecine doğrudan ve aktif katılması ile açığa çıkan yerel bilgi, beceri ve sosyal sermaye gibi faktörlerin kullanabileceği anlamina gelmektedir.

5449 sayılı kanun ajansın görev ve yetkilerini tanımlarken 5. maddesi, "bölge plân ve programlarına uygun olarak bölgenin kırsal ve yerel kalkınma ile ilgili kapasitesinin geliştirilmesine katkıda bulunmak ve bu kapsamdaki projelere destek sağlamak" olduğunu ifade eder. Ancak BKA’nın kırsal kalkınmayı ne ölçüde destekledikleri ve özellikle uygulamada katılımcı süreçleri nasıl işlettiklerinin daha yakından incelenmesi gerekmektedir. Aslında 
BKA'nın dayanağı olan 5449 sayılı kanun bize bu soruların cevabını kısmen de olsa vermektedir. BKA'ların plan ve stratejilere ilişkin karar organları olan kalkınma kurulu ve yönetim kurullarında kırsal kesimi temsil eden aktörler yer almamaktadır. BKA tek ilde kurulu ise yönetim kurulu ilin valisi, büyükşsehir belediye başkanı, il genel meclis başkanı, sanayi odası başkanı, ticaret odası başkanı ile kalkınma kurulu tarafından özel kesim ve/veya sivil toplum kuruluşlarından seçilecek üç temsilciden oluşmaktadır. Diğer taraftan eğer BKA birden fazla ili kapsıyorsa, yönetim kurulu il valileri, belediye başkanları ve büyükşehir olmayan illerde il merkez belediye başkanları, il genel meclisi başkanları ve her ilden birer kişi olmak kaydı ile ticaret ve sanayi odası başkanlarından meydana gelir (mad.10). Örneğin ekonomisinde tarım ve hayvancılığın önemli bir ağırlığının bulunduğu Diyarbakır ve Şanlıurfa illerini kapsayan Karacadağ Kalkınma Ajansının resmî sitesine göre, altı kişiden oluşan yönetim kurulu Diyarbakır ve Şanlıurfa valileri, iki ilin Büyükşehir başkanları ile sanayi ve ticaret odaları başkanlarından meydana gelmektedir.

Aynı kanunun 8 maddesi ise diğer bir karar organı olan kalkınma kurulunu düzenlemektedir. Buna göre, bu kurul illerin dengeli temsilini sağlayacak şekilde ve en fazla yüz üye olmak üzere bölgedeki kamu kurum ve kuruluşları, özel kesim, sivil toplum kuruluşları, üniversiteler ve yerel yönetim temsilcilerinden” oluşturulur (mad. 8). Görülebileceği gibi, genel kurul üyeleri genelde kentte faaliyet gösteren kamu kesimi, özel sektör ve sivil toplum kuruluşlarının temsilcileridir. Çoğunlukla bulundukları bölgenin şehir merkezinde faaliyetlerini sürdüren özel sektör ve sivil toplum kuruluşların ülkemizin kırsal sorunlarını ne ölçüde bildikleri ve kırsal kesimin çıkarlarını ne ölçüde veya samimiyetle savunacakları tartışmalıdır. Cankorkmaz (2011, s. 128)' in doğru bir şekilde tespit ettiği gibi, yönetim kurullarında ziraat odasından herhangi bir temsilcinin yer almaması tarım ağırlıklı bölgelerde kurulan BKA'lar açısından alınan kararların uygulanmasını sekteye uğratabilir (Cankorkmaz, 2011, s. 128). Karar organlarında kırsalı temsil eden üyelerin bulunmaması, esasında aşağıda tartışılacağı üzere kırsal kalkınma açısından daha da büyük sorunlara yol açmaktadır.

Sayıları az olsa da Türkiye'deki BKA'ları konu alan iki çalışmada bu kurumların hem kırsal kalkınma projelerine verdikleri destekler hem de katılımı sağlamada oldukça yetersiz kaldıkları belirlenmiştir (Güney vd., 2016, s. 103; Işıç̧ı, 2018, s. 421). Batı Akdeniz, Doğu Anadolu, Doğu Karadeniz, Güney Ege, İpekyolu, Karacadağ ve Trakya Kalkınma Ajanslarının 2015-2016 yılları için faaliyet raporları ve bölge Planları ile çalışan uzmanlarla yapılan görüşmelere dayanan bir çalışmada, kırsal kalkınmaya katkılarının sınırlı kaldığı tespit edilmiştir. Bu ajansların kırsal alanlara yönelik olarak daha çok girişimcilik ve rekabet odaklı projeleri destekledikleri ve bunun da ürün çeşitliliğinin ve veriminin artırılması hedefi ile sınırlı kaldığı belirlenmiştir. Diğer taraftan kırsal kesimin desteklenen projeleri hem sayı hem de finansal destek miktarı olarak değer sektörlere kıyasla çok düşük bir düzeyde kalmıştır (Işıkçı, 2018, s. 421).

\begin{tabular}{|c|c|c|c|c|c|}
\hline \multirow[t]{2}{*}{ Yil } & \multicolumn{2}{|c|}{ Desteklenen proje say1s1 } & \multicolumn{2}{|c|}{$\overline{\text { Destek miktarı (Milyon TL) }}$} & \multirow{2}{*}{$\begin{array}{c}\text { Kirsal finansal } \\
\text { destek }(\%)\end{array}$} \\
\hline & Toplam & Kirsal & Toplam & Kırsal & \\
\hline 2015 & 1300 & 51 & 471,9 & 16.5 & 3.5 \\
\hline 2016 & 764 & 48 & 282.8 & 10.3 & 3.6 \\
\hline
\end{tabular}


Işıkçı' nın (2018) bu çalışmasında 2015 ve 2016 yılları için tespit ettiği proje sayıları ve destek miktarlarının kırsal ve diğer sektörler arasındaki dağılımı, yukarıda tablo olarak verilmektedir. Buna göre, 2015 yllı içinde sözü geçen kalkınma ajanslarının destekledikleri toplam proje sayısı 1300 iken bunların sadece 51 adeti $(\% 3,9)$ doğrudan kırsal kalkınma ile ilgiliydi. Aynı dönemde bu projelere verilen toplam finansal destek 471,9 milyon TL iken, kırsalın payı \%3,5 civarında kalmıştır. Bu veriler 2016 yılı içinde benzer bir durumun geçerli olduğunu göstermektedir. Kalkınma ajanslarının kırsal sektöre verdiği desteğin bu ölçüde az olmasının, ajansların karar verme organlarında kırsal çıkarı temsil edecek üyelerin bulunmamasının etkisinin olduğu iddia edilebilir. Öte taraftan Işıkçı' ya (2018, s. 421) göre, bu ajansların tarımsal üretim ve hayvancılık, sosyal ve kültürel etkinliklerden mahrumiyet gibi kırsalın en önemli sorunlarını göz ardı etmektedirler. Görüşmelerde uzmanlar kırsalın birçok temel sorunun bulunmasına rağmen kalkınma kuruluşlarına bunlara ilişkin sorumluluk yüklenmediğini ifade etmişlerdir. Yine bu görüşmelerde kırsalın farkındalığının yeterince anlaşılmaması, kırsal kalkınma projelerinin hazırlanmasında yaşanan zorluklar, kırsaldaki diğer aktörler ile koordinasyon sıkıntısı, stratejik planlamalardaki yetersizlikler gibi sorunlara dikkat çekilmiş ve bütün bunların kırsala yönelik kendi faaliyetlerini de olumsuz etkilediğini belirtmişlerdir (Işıkçı1, 2018, s. 438). Yazara göre, mülakatlar ve BKA' nın incelenen belgeleri, ajansların 'kırsal kalkınma sorununa daha çok girişimcilik, rekabet açısından bakmakta ve kırsala yönelik daha çok, proje hazırlama, $A B$ fonlarından yararlanma konusunda danışmanlık etme ve çiftçi eğitimlerinin gerçekleştirilmesi şeklinde katkı" sağlamaya çalışmışlardır (Işıkçı, 2018, s. 438). Diğer taraftan kırsaldaki "insan gücünün niteliği, sosyal ve ekonomik kalitesinin artırılması ve çevre koruma" gibi etkenlerin göz ardı edildiği belirlenmiştir (Işı̂kçı, 2018, s. 439-440).

Güney vd. (2016) ise İzmir ve Batı Karadeniz Kalkınma Ajansları örnekleri bağlamında katılımı incelerler. Mevcut durumun tespiti, "farkındalı̆̆ arttırma ve haberdar etme, eyleme yönelik araçlar hazırlama ve katılım sürecinin işletilmesi ve sürdürülebilirliğinin sağlanması" kapsamında değerlendirmiştir (Güney vd., 2016, s. 105). Çalışmada, katılım açısından bölge planlarının hazırlık aşamalarında önemli bir mesafe kat edilmiş olduğu, ancak uygulama ve gözden geçirmede ilgili tüm aktörlerin katılımına olanak sunan bir yönetişim yapısının tasarlanması gerektiği ve bunun da merkezin planları dikte etmekten vazgeçmesi ile mümkün olacağı iddia edilmektedir (Güney vd., 2016, s. 114). Kararların "aşağıdan yukarıya doğru işleyen bir süreç, yöntem ve ortak akıl içermesi yönünde iken sürecin bu şekilde işlemediği”" belirlenmiştir. Genel olarak katılımın önemli olduğu konusunda bir fikir birliği olsa da uygulamada sürecin farklı işlediği ve katılımın yetersiz kaldığı belirlenmiştir (Güney vd, 2016, s. 113).

Katılımın çok sayıda ve farklı faydalar sağlayabileceği konusunda genel bir uzlaşının olduğu söylenebilir. Arnstein bu anlamda katılımı ıspanağa benzettir. Onun sözleriyle "illkesel olarak hiç kimse ona karşı değildir; çünkü sizin için iyidir” (Arnstein, 1969, s. 216). Kamu yönetiminde katılımın teşvik edilmesi gerektiği birçok gerekçe ile açıklanabilir. Bir kere yasalar ya da merkezi hükümet, bazı programların uygulanmasında katılımı zorunlu kılabilmektedir (Marın, 2007; Wilcox 1994, s. 64). Bürokrasinin büyümesiyle yöneten ile yönetilen arasındaki mesafe açıldığı gibi normal bürokratik mekanizma ve bilgi kaynakları dezavantajlı kesimlerin (kadın, dar 
gelirliler ve engelliler gibi) taleplerini iletebilmelerine engel olabilmektedir (Marın, 2007, s. 423424; Wilcox, 1994, s. 64). Bu nedenle karar veren organlar kararlarına yansıtabilmeleri için vatandaşların tercihlerini öğrenme ihtiyacı duymakta (Marın, 2007, s. 423-424) ve başta dezavantajlılar olmak üzere her kesimin katılımı toplumsal adalet ve eşitlik ilkelerinin gerçekleşebilmesinin bir yolu olarak görmektedir (Marın, 2007, s. 423-424; Wilcox 1994, s. 64). $\mathrm{Bu}$ anlamda katılım, giderek dünyada adaleti sağlamanın yolu ve evrensel bir değer olarak da pazarlanabilmektedir (Barreteau vd., 2010, s. 2). Yine vatandaşların kendilerini etkileyen kararları etkileme arzusu ile kamu hizmetlerinin sağlanmasına katılmayı da talep etmeleri; alınan kararların farklı kesimlerce kabul edilmesi ve sahiplenmesi için, bunları etkileyebilme olanağına sahip olabilmeleri; artan memnuniyetsizlikleri giderilmesi amacıyla bazı hizmetlerin sunumlarında yetkinin desantralize edilmesi ya da yerel topluluklara devri ihtiyacı (Wilcox 1994, s. 64; Marın, 2007, s. 423-424) diğer bir grup gerekçeyi oluşturmaktadır. Son olarak yerel toplulukların içinde yaşadıkları koşulları ve sorunlarını daha iyi bilmeleri dolayısıyla katılımlarının daha etkili çözümlerin üretilmesine, kamu hizmetlerinin daha etkili ve verimli sunumuna katkı sağlayabileceği düşünülmektedir (Wilcox, 1994, s. 64; Marın, 2007, s. 423-424; Gow ve Vansant, 1983, s. 427).

Gow vd. (1983, s. 427) insanların önemli olduğunu düşündükleri sorunlar etrafında daha kolayca bir araya gelebildiklerini ve iyi örgütlenebildiklerine dikkat çeker. Yine proje faaliyetleri için gönüllü işgücü, zaman, para ve diğer maddi katkıların yapılması, bağımlılıktan ve pasiflikten kurtulmak için zorunlu bir ön koşuldur. Son olarak kalkınma faaliyetlerinin türü, kalitesi ve yararları üzerinde yerel kontrolün kurulması, sürecin kendini devam ettirmesine yardımcı olur. Örneğin Kenya'nın Nandi bölgesindeki bir çalışmada proje etkinliği ile katılım seviyesi arasında pozitif bir ilişki bulunmuştur (Rono vd., 2003, s. 88-97).

Katılım yerel bilgi ve sorunların anlaşılmasına dayandığı zaman, yerel ihtiyaçlarla daha çok ilgili olur. Bu kapsamda kırsal kalkınmadan en çok etkilenecek kesimleri belirleme yoluyla faydaların en yoksul kesimlere gitmesindeki isabeti artırır. Özellikle insanların yerel kaynak ve becerileriyle katkı sağlamaları, kalkınma faaliyetlerinin verimliliğini artırır (Chhetri, 2013, s. 1484). Katılım planlanması ve uygulanmasında yer alanlar, yeni fikirler ve ayni katkılar sağlayabilir. Bu hem daha kaliteli ürün veya iyi sonuçların ortaya çıkmasına, hem de kırsal kalkınma için gerekli olan öz yeterlilik, kişisel özgüven ve becerilerin gelişmesine yardımcı olur. Özellikle erken dönemde fikirlerde payları olanların, uzum dönem çözümlerin parçası olma ihtimali de yükselir (Wilcox, 1994, s. 34; Chhetri, 2013, s. 1484). Katılım, yerel kapasite ve yerel topluluğun kalkınma yeteneklerinin geliştirilmesi yoluyla kalkınma faaliyetlerinin yönetimi ve buna ilişkin müzakere etme becerilerini kazandırır. Katılım sürecinde yerel topluluk sorumluluk yükünün bir kısmını üstlenebildiği zaman, yapılacak faaliyetlerin kapsamın genişletilmesine de yardımcı olur (Chhetri, 2013, s. 1484). Paydaşların programların yerel düzeyden ulusal ölçeğe varıncaya kadar her aşamasında katılımı, kaynakların sürdürülebilir yönetimine ilişkin sorunları çözmenin etkili bir yoludur (Claridge, 2004, s. 26). Katılım daha sonraki çalışmalarda da önem arz edecek ortak anlayış, güven ve özgüvenin gelişmesine katkı sağlar. Katılımla ilgili kararlarda etkili olduğunu düşünenler, daha olumlu bir tavır takınırlar (Wilcox, 1994, s.34). Toplukların katılım gösterdikleri kararlardan daha fazla memnun oldukları ve hatta bu kararların sonuçları beklentilerinin tersine çıktığında da olumlu tavırlarının devam ettiği belirlenmiştir (Jones vd., 2013, s. 10). 
Diğer taraftan katılımın hedefleri çok farklı kavramlara, faaliyet ve sonuçlara ilişkindir (O'Faircheallaigh, 2010, s. 19-20). Yine katılımın fayda ve sorunları farklı kesim ve çıkarlara göre değişir (Wilcox, 1994, s. 34). Örneğin halkla bilgileri paylaşmak, toplulukların kararları etkilemelerine olanak verme ya da bireyleri ve toplulukları güçlendirmeden oldukça farklıdır. $\mathrm{Bu}$ gerçeği dikkate aldığımızda, amaçları ve her birisinin ne ile ilgili olduğu ve ne anlama geldiğini göz ardı ederek "etkili katılımın" ne olduğu da tartışmalı hale gelir. İkincisi katılım kavramının birçok farklı şeyi kapsayabileceği ortadayken, katılımın faydaları konusunda literatürde ortak bir görüşün bulunduğu iddiası, bir gerçeklikten ziyade bir varsayımdır (O'Faircheallaigh, 2010, s. 20).

Bireysel sosyoekonomik değişkenlerin katılımla ilişkileri olduğunu gösteren çok sayıda yerli ve uluslararası çalışma bulunmaktadır (Defrancesco, Gatto, Runge ve Trestini, 2008; Leighley, 1995; Ertuna vd., 2012). Bulgulara göre, çok farklı siyasal katılım türlerinin genel olarak eğitim ve gelirle pozitif ilişkisi bulunmaktadır. Bu çalışmalarda cinsiyet ve etnik yapı değişkenlerinin katılımla olan ilişkileri ise, daha karmaşı bir özellik gösterir (Leighley, 1995). Siyasal katılıma ilişkin bir çalışmada eğitim, gelir ve cinsiyet kontrol edildikten sonra, katılımın yaşla birlikte arttığı, ancak faaliyetlere katılımın zorluk derecesine bağlı olarak ileriki yaşlar için azaldığı belirlenmiştir. Genç nüfusun nispeten hareketli yapısı, toplulukla da daha az bütünleşmelerine (Leighley, 1995, s. 183-184) ve dolayısıyla topluluk işleriyle ya da katılımla daha az ilgilenmelerine yol açar. Diğer taraftan kırsal turizm algısı ve katılımının incelendiği bir çalışmada, genç yaştaki katılımcıların kırsal turizme ilişkin sosyal algı ile katılım skorlarının, yaşlı olanlarınkine kıyasla daha yüksek çıkmıştır (Ertuna vd., 2012, s. 65). Kadın çiftçilerin organik tarımı benimseme eğilimlerinin incelendiği bir araştırmada ise, katılımlarının yaş ile negatif, ancak eğitim programlarına ilişkin deneyim, gelir düzeyi, arazinin mülkiyeti ve büyüklüğü ile de pozitif korelasyona sahip olduğu belirlenmiştir (Kaya ve Atsan, 2013, s. 4448). Tescil ettirilen pamuk çeşitlerini benimseyen grubun önemli ölçüde genç ve yüksek eğitime sahip olduğu, buna karşllk gelir düzeyi, kooperatif üyeliği, köy yönetimine katılım ve tarımsal yatıım durumlarının etkisinin olmadığı belirlenmiştir (Kaynak ve Boz, 2014, s. 31-32).

Ohmer'e (2010) göre, topluluk örgütlenmelerinde rol alanların beklentileri, kişisel ve siyasal öz yeterlilikleri de yüksektir. Bu tür örgütlenmeler içinde daha fazla yer alanların, siyasal öz yeterlilikleri, kontrol etme arzuları ve görev alma istekleri de yüksektir. Ayrıca örgütlenme deneyimine sahip kişiler, başarılarının dış yardımlardan çok kendi çabalarının bir ürünü olduğu konusunda genel bir inanç beslerler (Ohmer, 2010, s. 7). Bir çalışmaya göre de daha iyi örgütlenmiş veya örgütlenmeleri dışardan teşvik edilmiş insanlar ile kalkınma projelerinin planlama ve uygulamalarına bilgileri aktarılmış olanların, projenin sona ermesinden sonra da finansal destek ve kalkınma faaliyetlerini sürdürdükleri belirlenmiştir (Bass, Dalal-Claytonve Pretty, 1995). Geçmiş deneyim, katılım konusu, programın kolaylı̆̆ı ve katılım maliyetlerinin karşılanmış olması, genelde katılımı teşvik etmektedir (Defrancesco vd., 2008, s. 114).

Birçok yazara göre, katılım açısından tarımsal işletmelerin yapısal faktörlerini oluşturan işletme büyüklüğü, işletme türü ve işgücü içinde işletmenin büyüklüğü, katılımı etkileyen en önemli etkendir. Ancak bu konudaki bulgular çelişkilidir. Birkaç çalışma işletme büyüklüğünden 
ziyade işletme türünün katılımda daha önemli olduğunu belirlemiştir. Bir araştırmada ise emek yoğun tarımsal üretim türleri ile aile gelirinin önemli ölçüde tarımsal faaliyetlere bağlı olmasının katılımı engellediği belirlenmiştir (Defrancesco vd., 2008, s. 117).

\section{Köykent Projesine iliş̧kin Önceki Çalışmalar}

Köykent proje sürecindeki katılıma ilişkin birkaç çalışma bulunmakla birlikte ya kavramsal düzeydeki tartışmalar biçiminde ya belirli ve sınırlı sayıda kişileri kapsamakta ya da tesadüfi olmayan örneklemlere dayanmaktadır. Erdönmez (2005) ile Koç ve Gül'ün (2006) çalışmaları, doğrudan Köykent projesi kapsamındaki köyleri ele aldıkları için önem taşımaktadırlar. Ancak Erdönmez'in (2005) çalışması alana yapılan ziyaretlerden elde edilen izlenimler, yerel halk, kamu ve yerel yöneticilerle yapılan yüz yüze görüşmelerden elde edilen verilere dayanmaktadır. $\mathrm{Bu}$ çalışmanın nitel doğası katılım için genelleştirmeler yapmaya engel olmaktadır. Koç vd'nin (2006) çalışması bu duruma bir istisna teşkil etse de doğrudan katılımı konu almamaktadır. Bu çalışmanın örneklemi otuz tarımsal işletme sahibi ile sınırlı olup söz konusu tarımsal işletmelerin iktisadi yapısını analiz etmektedir.

Mesudiye Kurultayını ve dernekleri yönetişim ve siyaset bilimi açısından inceleyen iki ampirik çalışma da bulunmaktadır (Aydınlı ve Memiş, 2014; Kovancı, 2005). Bu çalışmalar nadiren de olsa proje alanındaki köylerdeki katılıma ilişkin yorumlar yapmaktadır. Ancak bu çalışmaların nitel özellikleri ve esas amaçlarının farklı olması, köykent projesindeki katılıma ilişkin kapsamlı değerlendirmelere engel olmaktadır. Diğer taraftan Başa (2000, 2001 ve 2009) gibi doğrudan projenin her aşamasında yer almış ve konuya ilişkin deneyimlerini paylaşan, teorik bir açıdan projeyi değerlendiren (Marin, 2005), kırsal kalkınma kapsamında konuya bakan (Çolakoğlu, 2012), bir tür kalkınma modeli olarak değerlendiren (Güler, Çırakoğlu ve Tokmak, 2014) veya konuyu yönetsel boyutu ile inceleyen (Yıldız vd., 2009) çalışmalar da bulunmaktadır. Sonuç olarak Köykent projesinin ne ölçüde katılımcı bir anlayışa dayandığı ve uygulamada katılımın niteliği ile katılımı etkileyen sosyoekonomik ve demografik özellikleri belirlemeye yönelik hiçbir çalışmanın bulunmadığı söylenebilir.

\section{Araştırmanın Yöntemi}

$\mathrm{Bu}$ kısımda, çalışmanın dayandığı araştırma türü kısa da olsa açıklanmakta ve sonrasında kullanılan yönteme ilişkin bilgiler verilmektedir. Araştırma yaklaşımlarını çok genel olarak nicel ve nitel olarak iki grup altında toplayabiliriz. Nicel araştırma, nesnel teorileri ya da buna dayanan ve sayısal olarak ifade edilebilen değişkenler arasındaki ilişkileri test etmeye yönelik bir yaklaşımdır. Bu yaklaşım, istatistiki teknikler aracılığıyla bir teori tarafından açıklanan sosyal olguyu meydana getiren değişkenler arasındaki ilişkileri belirlemeye çalışırken, alternatif açıklamalar, aracı veya karıştırıcı değişkenleri de istatiksel olarak kontrol eder. Buna göre bir teori tümden gelim yoluyla test edilir, elde edilen sonuçlar tüm anakütleye genelleştirilir ve çalışma tekrar edilebilir (Creswell ve Creswell, 2018, s. 41). Bu araştırmanın amacı Mesudiye Köykent Projesi sürecine tüm hane halkı reislerinin ne ölçüde katıldıklarını ve bunu etkileyen sosyoekonomik ve demografik özellikleri belirlemek olduğu için, genelleme yapmaya ve değişkenler arasındaki ilişkileri belirlemeye imkân veren nicel bir yaklaşım benimsenmiştir. Bu ise ancak bütün proje bölgesinde yaşayan hane halkı reislerini temsil eden ve dolayısıyla 
genellemelere izin verebilecek olasılığa dayalı bir örneklem, veri toplama aracı ve istatistiki tekniklerin seçimi ile mümkün olabilir. Dawson' un (2009, s. 15) da belirttiği gibi, tüm ana kütleyi temsil edebilecek tesadüfi bir örneklemin seçilmesi ve bunlardan kısa süre içinde toplanacak kapsamlı verilerin elde edilmesini sağlayacak veri toplama aracı da ankettir. Sonuç olarak bu makalenin amacı ve araştırma soruları açısından ana kütleyi (köykent hane halkı reisleri) temsil edebilen bir örneklemden toplanan sayısallaştırılmış değişkenleri kullanarak, tüm köykent haneleri için istatistiki olarak anlamlı ilişkileri belirmek önem taşımaktadır. Bu da ancak nicel bir araştırma ile mümkün olabilir.

\section{Araştırma Alanı}

Projenin yürütüldügü Çavdar merkez ve etrafındaki diğer sekiz köy Ordu'nun Mesudiye İlçesine bağlı olup (Bkz. Resim 1), ilçe merkezine oldukça yakındır. Doğu Karadeniz ile Orta Karadeniz'in ve İç Anadolu ile Karadeniz bölgelerinin kesiştiği noktada yer alan Mesudiye'nin önemli bir bölümünde İç Anadolu'dakine benzer bir karasal iklim hâkimdir. Ordu ilinin bu en geniş ilçesi, deniz seviyesinden bin eli metre yüksekliktedir (Dinçer ve Özaslan, 2004). DPT (2004) tarafından yaptırılan İlçelerin Sosyo-ekonomik Gelişmişlik Sıralaması Araştırması'nda, Mesudiye 872 ilçe arasında 611. sırada ve 4. gelişmişlik grubunda yer almaktadır (DPT, 2004; Dinçer ve Özaslan, 2004).

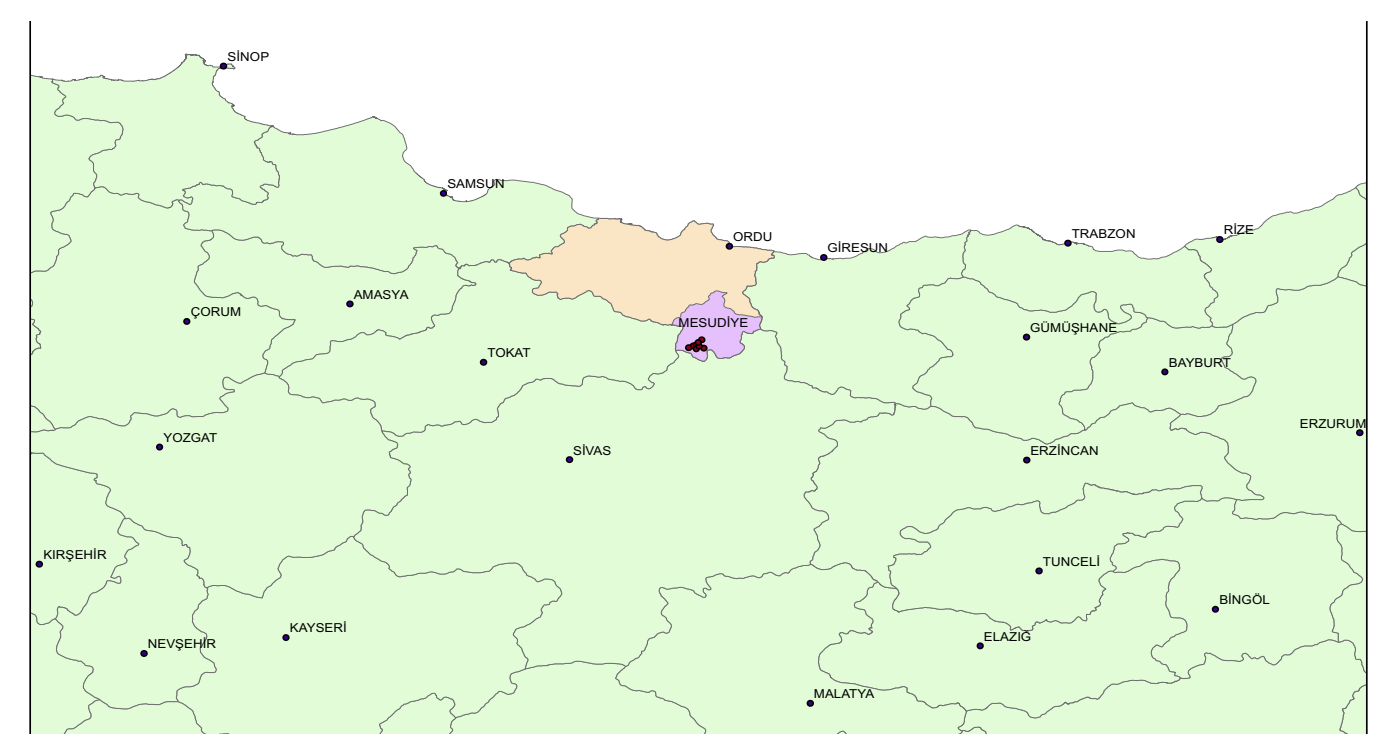

Şekil 1. Köykent Proje Alanın Türkiye'deki Konumu 


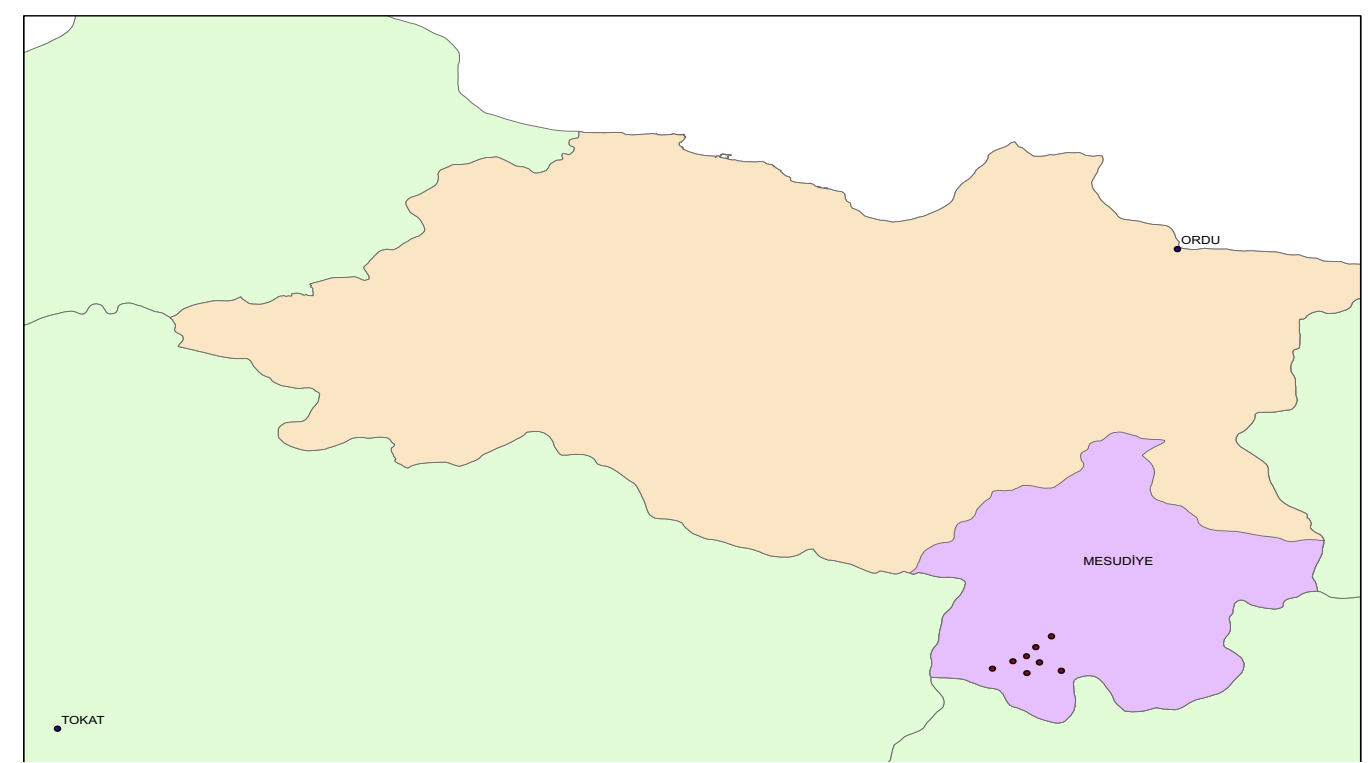

Şekil 2. Köykent Projesinde Yer Alan Köy Merkezlerinin Mesudiye İlçesi’ndeki Konumu

Mesudiye ilçesinin doğal yapısı, ormanlık alanlar, otlak ve meralardan oluşmaktadır. Dağlık yapısı, tarıma elverişli geniş toprak varlığının oluşumunu sınırlandırmaktadır.

Doğu Karadeniz Kalkınma Ajansının (DOKA), 2015 yılında 33 değişken ve temel bileşenler analizi kullanarak TR90 Bölgesini oluşturan Trabzon, Ordu, Giresun, Rize, Artvin ve Gümüşhane İllerine bağlı 79 ilçe için yapmış olduğu sosyoekonomik gelişmişlik sıralaması çalışmasında Mesudiye ilçesinin kalkınma düzeyi bakımından 78. sırada ve en alt kademe olan 10. derece ilçeler grubu içinde yer aldığını tespit etmiştir (s. 8). Analizde kullanılan 33 değişken, demografi ve yaşam kalitesi, ekonomik ve mali, eğitim, sağlık, rekabet ve yenilik kapasitesi göstergelerini meydana getirmektedir (s. 5). Çalışmada her ilçe hem bölge hem de bağlı oldukları ilin diğer ilçeleriyle karşılaştırılmaktadır. Sonuçlara göre, yaşam kalitesi endeksi açısından Mesudiye bölge içinde 77 ve Ordu'ya bağlı toplam 19 ilçe içinde 18. sırada gelmektedir. Mesudiye' nin diğer endeksler açısından bölgedeki 79 ve Ordu’ya bağlı 19 ilçe ile kıyaslanmasının sonuçları ise sırasıyla şöyledir: eğitim endeksinde 76 ve 17, sağlık endeksinde 75 ve 15 , ekonomi ve mali endekste 54 ve 13 ve son olarak rekabet ve yenilik kapasitesi endeksinde 74 ve 16. sıralarda gelmektedir (Berber, Genç ve Yıldız, 2015, s. 78-89).

Köykent projesi alanını meydana getiren köylerin özellikleri Tablo 1'de verilmektedir. Buna göre, projenin merkezi olan Çavdar, Mesudiye ilçe merkezinden $18 \mathrm{~km}$ ve proje merkezinin en uzağındaki Yuvalı ise $31 \mathrm{~km}$ mesafede yer almaktadır. Bölgenin dağlık yapısı ve bozuk yolları, Mesudiye ile Ordu arasındaki ulaşım güçleştirmekte, 130 km'lik mesafe bazen 3 saatten fazla zaman alabilmektedir. Kar yağışının yoğun olduğu kış aylarında ise, Köykentin diğer yerleşimlerle olan ulaşımı kesilebilmektedir. 
Tablo 1. Mesudiye Köykent Projesi Kapsamındaki Köylerin Nüfusları, Ordu ve Mesudiye'ye Mesafeleri

\begin{tabular}{llllc}
\hline Köy & $\begin{array}{c}\mathbf{2 0 0 7} \text { yılı Adrese Dayalı } \\
\text { Nüfus }\end{array}$ & $\begin{array}{c}2007 \text { yılı tahmini hane } \\
\text { halkı sayısı }\end{array}$ & $\begin{array}{c}\text { Ordu'ya } \\
\text { Uzaklık (km) }\end{array}$ & $\begin{array}{c}\text { Mesudiye'ye } \\
\text { Uzaklık (km) }\end{array}$ \\
\hline Çavdar & 126 & 24 & 133 & 18 \\
Çardaklı & 60 & 11 & 133 & 18 \\
Day1lı & 192 & 37 & 131 & 16 \\
Esatlı & 132 & 25 & 122 & 7 \\
Göçbeyi & 99 & 19 & 133 & 18 \\
Ilışar & 117 & 22 & 122 & 7 \\
Kişlacik & 54 & 10 & 129 & 14 \\
Türkköyü & 62 & 12 & 127 & 12 \\
Yuvalı & 20 & 4 & 136 & 31 \\
TOPLAM & 862 & 164 & 1166 & 141 \\
\hline
\end{tabular}

Kaynak: 2007 yılı TÜİK Adrese Dayalı Nüfus Kayıt Sistemi (ADNKS) verileri

\section{Veri Kaynakları ve Veri Toplama Aracı}

Bu çalışmanın temel verisi, 4-12 Haziran 2008 tarihlerinde TÜBİTAK tarafindan 107K152 nolu proje olarak desteklenen ve Ordu İlinin Mesudiye İlçesi sınırları içindeki Çavdar merkezli Köykent projesi alanında dokuz köyde (Bkz. Tablo 1) yüz kırk dokuz hane halkı reisiyle yüz yüze yapılan bir anket çalışmasından gelmektedir. Bu verilerin yanı sıra, TÜİK' in sosyoekonomik ve demografik verileri, Köykent projesine ilişkin resmî belgeler, Mesudiye Kurultayının projeye ilişkin yayınları ve internet haberlerinden meydana gelen ikincil veri kaynakları da kullanılmıştır.

Uygulanan anket, hane halkı reislerinin sosyal ve demografik özellikleri, ekonomik etkinlikleri, köylere sağlanan fiziksel ve sosyal hizmetlerden memnuniyet, kırsal yaşamdan memnuniyet ve proje etkinliklerine katılım gibi konuları kapsamaktadır. Anketin katılıma ilişkin soruları, proje kapsamında gerçekleştirilen halk katılımının niteliğini belirlemeye yönelik beşli Likert ölçekli maddelerden oluşmaktadır.

\section{Örnekleme ve Verilerin Toplanması}

TÜIK'in Adrese Dayalı Nüfus Kayıt Sistemi (ADNKS) verilerine göre, 2007 yılında Proje alanında toplam sekiz yüz altmış iki kişi yaşamaktaydı. Bu nüfus, TÜİK’in Ordu için verdiği ortalama aile büyüklüğüne bölünerek her köy için ve toplamdaki hanehalkı sayısı belirlenmiştir. Araştırmanın amacı açısından, bulguların tüm nüfusu, bunu oluşturan köy ve farklı kesimleri temsil etmesine önem verilmiştir. Başka bir ifade ile bulguların genelleştirilebilmesine önem verilmiş ve bu yüzden de Orantılı Tabakalı Rassal Örnekleme türünün kullanılmasına karar verilmiştir. Tabakalı Rassal Örneklemde nüfus, grup veya alt tabakalara bölünür ve her tabakadan rassal bir örneklem alınır (Fink, 1995, s. 1). Farklı sosyoekonomik özelliklerinden dolayı bağımsız kuruldukları varsayılan her bir köy bir tabaka olarak tanımlanmış ve böylece dokuz bağımsız tabaka elde edilmiştir. Burada her tabakanın örnekleme oranı (fraction) ${ }^{3}$ aynı olmakta, ancak tabakalardaki örnekleme giren katılımcı sayısı değişebilmektedir. Örneklemeye girecek hanehalkı sayısı, aşağıdaki formül yardımıyla hesaplanmıştır (Yamane, 2001, s. 188):

\footnotetext{
${ }^{3}$ Örnekleme oranı $(\mathrm{f}=\mathrm{n} / \mathrm{N})$, her tabakaya ait örneklem hacminin toplam örneklem hacmine bölünmesiyle elde edilen bir değerdir.
} 


$$
n=\frac{N \sum N_{h} P_{h} Q_{h}}{N^{2} D^{2}+\sum N_{h} P_{h} Q_{h}}, D^{2}=\left(\frac{d}{z}\right)^{2}
$$

Bu eşitlikte, $n$ örneğe giren hanehalkı sayısı, $N$ ana kütlede bulunan hane halkı sayısı, $N_{h}$ her bir tabakadaki hanehalkı sayısı, $P_{h}$ her bir tabakadaki oranları, $Q_{h} 1-\mathrm{P}_{\mathrm{h}}$ değerini, $D^{2}$ arzu edilen varyansı, $d$ ana kütle ortalamasından izin verilen hata miktarı ve $z$ ise izin verilen güvenlik sınırının $t$ dağılım tablosundaki değerini göstermektedir. Örneklem hacminin belirlenmesinde $\% 5$ hata payı $(d)$ ve $\% 95$ güven sınırları (örneğin $z=2$ ) kabul edilmiştir. Bu formül yardımılla belirlenen örnek büyüklükleri $N_{h} / N$ formülüne göre oransal olarak tabakalara dağıtılarak, her bir tabakadan anket yapılacak hane halkları reisleri tesadüfî olarak seçilmiştir. Tabakalı örneklem, standart hatanın azalması, farklı özellikler taşıyan grupların (tabaka) temsil edilmesi ve analizlerin güvenirliliğini sağlar (Henry, 1990, s. 99-101). Sonuçta 9 köyden toplam 149 hanehalkı reisi belirlenmiştir.

Her köy için örneklem seçimi köy muhtarlarının verdiği bilgiler ve sağladıkları listelerin kullanılmasıyla gerçekleştirilmiştir. Örneklem çerçevesi olarak kullanılabilen bir listenin bulunmadığı köylerde ise, öncelikle basit tesadüfî yöntemle bir sokak belirlenmiş ve önceden belirlenen kural gereği sokak boyunca önce sağ taraftaki konutlardan 2., 4.ve 6. şeklinde sayılara karşılık gelen konutlardaki hanehalkı reisiyle görüşülmüştür. Sokağın sağ tarafındaki konutlar bittiğinde ise sol tarafta yer alan konutlardan aynı usulle göre devam edilmiştir.

\section{İstatistiki Model}

Araştırmada kullanılan sıralı logit model $y_{i}=\beta^{\prime} x_{i}+\varepsilon_{i}(1)$ şeklinde ifade edilebilir. Bu eşitlikte $y_{i}$ gerçekte gözlemlenmeyen aralıklı bir değişken olan katılımı (proje etkinliklerine ayrılan zaman, işgücü ya da bilgi için sarf edilen çaba) göstermektedir. $y_{i}$ "Düşük" "Orta" ve "Yüksek" şeklinde düzeyi anlamlı olarak değişen kategorik bir değişkendir. $y_{i}{ }^{\prime} \mathrm{i}$ doğrudan gözlemleyemesek bile, onunla ilgili ve farklı düzeylere sahip $z_{i}$ değişkenini gözlemleyebiliriz. Bu çalışmada $z_{i}$ katılımla ilgili ifadelere verilen yanıtlarla ölçülmektedir. Yukarıdaki eşitlikte $\beta^{\prime}$ tahmin edilecek bir parametre vektörüdür ve $\varepsilon_{i}$ gözlemlere göre değişmeyen hatadır. Son olarak $x_{i}$ ise kişinin eğitim durumu ve geliri gibi sosyoekonomik ve demografik özellikleri göstermektedir. Sonneveld (2002)'in notasyonu ile sıralı düzeylere sahip $z_{i}$ (katılım) ile gözlemlenmeyen $y_{i}$ arasındaki ilişkileri aşağıdaki gibi ifade edebiliriz:

$$
z_{1}=1 \text { ĕger } y_{i}<\mu_{1}, z_{2}=2 \text { e } \text { ger } \mu_{1} \leq y_{i} \leq \mu_{2} \text {, ve } z_{3}=3 \text { ĕger } \mu_{3} \leq y_{i}
$$

Maksimum likelihood yöntemiyle $\beta^{\prime \prime}$ lar ve gerekli $\mu_{1}$, $\mu_{2}$ ve $\mu_{3}$ için eşik değerler hesaplanabilir. $z_{i}=1$ olma olasilığ $(P), P\left(z_{i}=1\right)=P\left(y_{i}<\mu_{1}\right)=P\left(\varepsilon_{1}<\mu_{1}-\beta^{\prime} x_{i}\right)=F\left(\mu_{1}-\beta^{\prime} x_{i}\right)$, $z_{i}=2$ olma olasıllğ $(P), P\left(z_{i}=2\right)=P\left(\mu_{1} \leq y_{i} \leq \mu_{1}\right)=P\left(\mu_{1} \leq \beta^{\prime} x_{i}+\varepsilon_{i}<\mu_{2}\right)$

$$
=P\left(\varepsilon_{i}<\mu_{2}-\beta^{\prime} x_{i}\right)-P\left(\varepsilon_{i}<\mu_{1}-\beta^{\prime} x_{i}\right)=F\left(\mu_{2}-\beta^{\prime} x_{i}\right)-F\left(\mu_{1}-\beta^{\prime} x_{i}\right)
$$

$$
\text { ve } z_{i}=3 \text { olma olasilığ }(P), P\left(z_{i}=3\right)=P\left(y_{i} \geq \mu_{2}\right)=P\left(\varepsilon_{i} \geq \mu_{2}-\beta^{\prime} x_{i}\right)=F\left(\beta^{\prime} x_{i}-\mu_{2}\right)
$$

Sıralı logit modelinde $\varepsilon_{i}$ 'nın lojistik bir dağılıma sahip olduğu varsayılır.

$$
\Lambda=\frac{1}{1+e^{-(\bullet)}} \quad(6) \text { şeklinde bir fonksiyon olup birikimsel dağılımı } 0 \text { ile } 1 \text { arasında uzanır. }
$$


Yukarıda sıralı logit için verilen eşitliklerin likelihood fonksiyonu

$$
\begin{aligned}
& L\left(\beta, \mu_{1}, \mu_{2}\right)=\prod_{y_{i}=1} \wedge\left(\mu_{1}-\beta^{\prime} x_{i}\right) x \prod_{y_{i}=2}\left(\wedge\left(\mu_{2}-\beta^{\prime} x_{i}\right)-\left(\mu_{1}-\beta^{\prime} x_{i}\right)\right) x \ldots x \prod_{y_{i}=N} \wedge \\
& \left(\beta^{\prime} x_{i} \mu_{N-1}\right)
\end{aligned}
$$

biçiminde ifade edilebilir. $\mathrm{Bu} L$ fonksiyonu $\beta, \mu_{1}, \mu_{2}$ parametreleri bakımından maksimize edilir.

\begin{tabular}{|c|c|c|}
\hline Değişkenler & Tanım & Beklenen etkiler \\
\hline $\begin{array}{l}\text { KatılımEtkinliği } \\
\text { (Bağımlı } \\
\text { Değişken) }\end{array}$ & $\begin{array}{l}\text { Faktör analizi sonucu belirlenen beşli Likert ölçekli katılımın düzeyi ve niteliğini ölçmeye } \\
\text { yönelik } 5 \text { ifadeye verilen yanıtların toplanarak 5'e bölünmesi ile elde edilen değerlerin üç } \\
\text { düzeyli kategorik değişkene dönüştürülmesiyle oluşturulan değişkendir. }\end{array}$ & \\
\hline ProjeEtkinliği & $\begin{array}{l}\text { Faktör analizi sonucu belirlenen beşli Likert ölçekli proje sonuçlarının benimsenme } \\
\text { düzeyini ölçmeye yönelik } 2 \text { ifadeye verilen yanıtların toplanarak 2’ye bölünmesiyle elde } \\
\text { edilen değerlerin üç düzeyli bir kategorik değişkene dönüştürülmesiyle oluşturulan } \\
\text { değişkendir. }\end{array}$ & \\
\hline Toprak & Eğer kişi toprak sahibi ise 1 , değilse 0 & + \\
\hline Okul & Eğer kişi en azından ilkokul mezunu ise 1 , değilse 0 & + \\
\hline Cavdar & Eğer kiși Cavdar köyünde yașıyorsa 1 , yoksa 0 & + \\
\hline Kooperatif & Eğer kişi en azından bir kooperatif üyesi ise 1 , değilse 0 & + \\
\hline Erkek & Eğer kişinin cinsiyeti erkek ise 1 , kadın ise 0 & + \\
\hline Köydeyaşam & Eğer kişi bir yıl boyunca en az 6 ay köyde yaşıyorsa 1 , yoksa 0 & + \\
\hline Tarım & Eğer kişi herhangi bir bitkisel üretim yapıyorsa 1, yapmıyorsa 0 & $?$ \\
\hline Hayvancllık & Eğer kişi hayvancılık yapıyorsa 1 , yapmıyorsa 0 & $?$ \\
\hline Gelir & Kişinin tüm farklı kaynaklarından elde ettiği aylık ortalama gelirinin doğal logaritması & + \\
\hline Yaş & Kişinin yaşının doğal logaritması & - \\
\hline
\end{tabular}

Tablo 2. Sıralı Logit Modelinde Kullanılan Değişkenlerin Tanımları ve Beklenen Etkileri

Modeldeki değişkenlerin tanımları ve beklenen etkileri Tablo 2'de verilmektedir. $\mathrm{Bu}$ modele göre, proje etkinliklerine katılım (PrejeEtkinliği), toprak mülkiyeti (Toprak), proje merkezi Çavdar köyünde ikamet etme (Çavdar), kooperatif üyesi olma (Kooperatif), erkek olma (Erkek), köyde yılda en az altı ay geçirme (Köydeyaşam), hayvancılık yapma (Hayvancılık), tarımla uğraşma (Tarım), aylık gelir (Gelir) ve yaşın (Yaş) bir fonksiyonudur.

\section{Bulgular}

Aşağıda proje alanına ilişkin betimleyici istatistikler ve araştırma sorularına ilişkin bulgular değerlendirilmektedir.

\section{Proje Alanındaki Hane Halkı Reislerinin Sosyoekonomik ve Demografik Özellikleri}

Tablo 3 anket çalışmasına katılanların, cinsiyet, eğitim durumu, kooperatif üyeliği, hayvancılık ve tarımsal üretim değişkenlerinin dağılımlarını göstermektedir. Toplam yüz kırk dokuz hanehalkı reisinin yer aldığı bu ankete katılanların, yüzde 16,8' i kadın ve geriye kalan \%83,2'si de erkeklerden oluşmaktadır. 
Tablo 3. Katılımcıların Sosyoekonomik ve Demografik Özellikleri

\begin{tabular}{|c|c|c|c|c|c|}
\hline Değişken & \multicolumn{2}{|c|}{ Evet } & \multicolumn{2}{|c|}{ Hayır } & $N$ \\
\hline & $\mathrm{n}$ & $\%$ & $\mathrm{n}$ & $\%$ & \\
\hline Erkek & 124 & 83,2 & 25 & 16,8 & 149 \\
\hline Okul & 114 & 76.5 & 35 & 23,5 & 149 \\
\hline Hayvancıllk & 53 & 35,6 & 96 & 64.4 & 149 \\
\hline Tartm & 40 & 26,8 & 109 & 73,2 & 149 \\
\hline Kooperatif & 13 & 9,1 & 130 & 90,9 & 143 \\
\hline
\end{tabular}

Katılımciların \%23,5'inin okuma yazması yokken, \%76,5'i en az ilkokul mezunudur. Katılımcıların \%35,6'sı hayvancılık ve \%26,8'i de bitkisel üretim yapmaktadır. Kooperatifleşme düzeyinin de \%9,1 gibi esasında oldukça düşük bir rakam olduğu görülebilir.

Tablo 4 ise katılımcıların en gencinin yirmi beş ve en yaşlısının da 81 yaşında oldukları ve 58,09 yıllık bir ortalamaya sahip oldukları görülüyor. Katılımcıların aylık gelirleri 2 ile 10,000 TL arasında değişirken 760 TL'nin biraz üzerinde bir ortalama gelire sahipler. Yine katılımcıların ortalama 39,47 dönüm araziye sahip oldukları görülüyor.

Tablo 4. Katılımcıların Yaş, Çocuk Sayısı, Toprak Mülkiyeti, Köyde Geçirdikleri Süre ve Aylık Gelirleri

\begin{tabular}{|c|c|c|c|c|c|}
\hline Değişken & Art. Orta. & Min. & Mak. & Std. Hata & $\mathbf{N}$ \\
\hline Yaş & 58,09 & 25 & 81 & 12,774 & 145 \\
\hline Çocuk sayısı & 4,63 & 0 & 9 & 1,94 & 144 \\
\hline Bir yılda köyde geçirilen süre (Ay) & 4,77 & 1 & 10 & 2,436 & 83 \\
\hline Sahip olunan toplam toprak (dönüm) & 39,47 & 0 & 1000 & 93,575 & 135 \\
\hline Aylık gelir & 760,9353 & 2,00 & 10000 & 926,13 & 139 \\
\hline
\end{tabular}

Katılımcılar yılda ortalama olarak 4,77 aylık bir süre için köyde kalmakta ve bu, kişiye göre 1 ila 10 ay arasında değişmektedir. Bu veriler ve yapılan görüşmeler, yıl içinde proje alanında ciddi bir demografik hareketliliğin olduğunu, özellikle soğuk kış aylarında çok az sayıda ailenin köylerde kaldığ 1 belirlenmiştir. Alanda yaşayan nüfusun önemli bir bölümü, okulların açılmasıyla Ekim ayı içinde başta İstanbul ve Ankara olmak üzere farklı şehirlere geri dönmektedirler.

\section{Köykent Projesi Kapsamında Katılımın Düzeyi ve Niteliği}

Resmî belge ve bazı çalışmalarda, projenin başarıya ulaşabilmesi için halk katılımının özendirildiği ve kooperatifler aracılığıyla örgütlenmelerine büyük önem verildiğinin altı çizilmektedir. Buna göre, katılım ve kooperatifler fiziksel altyapı yatırımlarını tamamlayacak olan ekonomik üstyapının temel dinamikleri olarak değerlendirilmektedir. "Köyünüzdeki halkın Köykent projesiyle ilgili kararlara katılımı nasıldı?” sorusuna verilen yanıtların dağılımı Tablo 5'te verilmektedir. Buna göre, katılımcıların \%17'si katılımın düzeyini oldukça düşük ya da düşük, \%38,1'i ortalama ve \%44,9'u da yüksek ya da oldukça yüksek olarak değerlendirmektedir. 
Tablo 5. Köydeki Proje Faaliyetlerine İlişkin Kararlara Katılımın Düzeyi

\begin{tabular}{lccc}
\hline & Frekans & Yüzde & Birikimsel Yüzde \\
\hline Oldukça düşük & 7 & 4,8 & 4,8 \\
Düşuk & 18 & 12,2 & 17,0 \\
Ortalama bir katılım & 56 & 38,1 & 55,1 \\
Yüksek & 41 & 27,9 & 83,0 \\
Oldukça yüksek & 25 & 17,0 & 100,0 \\
Toplam & 147 & 100,0 & \\
\hline
\end{tabular}

Tablo 6 köylerdeki insanların proje etkinliklerine kendi işgücü ve mali kaynaklarıyla katkıda bulunup bulunmayacaklarına ilişkin soruya verdikleri "evet" ya da "hayır" yanıtların dağılımını göstermektedir. Katılımcıların \%64,9'u bu soruyu olumsuz yanıtlarken, sadece \%29,1'i olumlu yanıtlamıştır.

Tablo 6. Köykent Projesi Gibi Kırsal Gelişme Amaçlı Faaliyetlere Isşgücü ve Para Desteği

\begin{tabular}{lccc}
\hline & Frekans & Yüzde & Birikimsel Yüzde \\
\hline Hayır & 96 & 64,9 & 64,9 \\
Fikrim yok & 9 & 6,1 & 70,9 \\
Evet & 43 & 29,1 & 100,0 \\
Toplam & 148 & 100,0 & \\
\hline
\end{tabular}

Bir başka soruyla da katılımcıların kalkınma girişimlerine verecekleri maddi ve manevi kişisel destek açısından kendilerini komşularıyla karşılaştırılmaları istenmiştir (Bkz. Tablo 7). Buna göre katılımcıların \%43,6'sı fikirlerinin olmadığını, \%22,8’i daha az, \%17,4’ü aynı oranda ve $\% 16,1$ ’i ise daha fazla destek sağlayacaklarını belirtmiştir.

Tablo 7. Köykentte Yaşayanların Komşu Köylere Kıyasla Ortak Bir Amaç İçin Maddi ve Manevi Katkıları

\begin{tabular}{lccc}
\hline & Frekans & Yüzde & Birikimsel Yüzde \\
\hline Daha az & 34 & 22,8 & 22,8 \\
Fikrim yok & 65 & 43,6 & 66,4 \\
Ayni oranda & 26 & 17,4 & 83,9 \\
Daha fazla & 24 & 16,1 & 100,0 \\
Toplam & 149 & 100,0 & \\
\hline
\end{tabular}

$\mathrm{Bu}$ bulgular, proje alanında yaşayanların birbirlerine daha az güvendikleri şeklinde yorumlanabilir. Proje alanında sürekli yaşamayanların nüfusun çoğunluğunu oluşturduklarını ve her birinin İstanbul, Ankara ve Bursa gibi çok farklı şehirlerden gelmeleri, böyle bir güvensizliğe yol açabilir. Sosyal sermayenin güven ile olan ilişkisi ve kalkınmadaki olumlu rolü düşünüldüğünde, bunun proje alanındaki kalkınma girişimleri için ciddi bir sorun oluşturabileceği açıktır.

Tablo 8 katılıma ilişkin üç soruya verilen yanıtların dağılımlarını göstermektedir. "Proje faaliyetlerine ilişkin karar ve çalışmalarda etkili oldum” şeklindeki ifadeye, katılımcıların \%60'ına yakını katılmazken, sadece \%25 kadarı katılmaktadır. Benzer olumsuz görüşler "planlamada görüşlerimize başvuruldu" $(\% 62,4)$ ve "faaliyetlerin yürütülmesinde görüşlerimize başvuruldu" $(\% 55,4)$ ifadeleri için de geçerlidir. 
Tablo 8. Planlama, Karar ve Uygulamaya Katılım Sorularına Verilen Yanıtların Dağılımı

\begin{tabular}{l|c|c|c|c|c|c}
\hline & \multicolumn{2}{|c|}{$\begin{array}{c}\text { Karar ve Çalışmalarda Etkili } \\
\text { Olduğumu Düşünüyorum }\end{array}$} & \multicolumn{2}{c|}{$\begin{array}{c}\text { Planlamada } \\
\text { Görüsşlerimize } \\
\text { Başvuruldu }\end{array}$} & \multicolumn{2}{c}{$\begin{array}{c}\text { Uygulamada } \\
\text { Görüsşlerimize } \\
\text { Başvuruldu }\end{array}$} \\
\cline { 2 - 7 } & $n$ & $\%$ & $n$ & $\%$ & $n$ & $\%$ \\
\hline Kesinlikle Katılmıyorum & 44 & 29,9 & 45 & 30,4 & 43 & 29,3 \\
\hline Kat1lmiyorum & 44 & 29,9 & 47 & 31,8 & 53 & 36,1 \\
\hline Fikrim yok & 22 & 15,0 & 17 & 11,5 & 15 & 10,2 \\
\hline Katıliyorum & 29 & 19,7 & 25 & 16,9 & 26 & 17,7 \\
\hline Kesinlikle Kat1lyorum & 8 & 5,4 & 14 & 9,5 & 10 & 6,8 \\
\hline Toplam & $\mathbf{1 4 7}$ & $\mathbf{1 0 0 , 0}$ & $\mathbf{1 4 8}$ & $\mathbf{1 0 0}$ & $\mathbf{1 4 7}$ & $\mathbf{1 0 0}$ \\
\hline
\end{tabular}

Buna karşılık her iki görüşe katılanların oranları sırasıyla $\% 26,4$ ve $\% 24,5$ düzeylerinde kalmaktadır. $\mathrm{Bu}$ bulgular gerek projenin hazırlanması ve planlanması gerekse proje faaliyetlerinin yürütülmesinde topluluk katılımının oldukça düşük düzeyde kaldığını göstermektedir.

Tablo 9 ise katılımın niteliği ve özellikle farklı çıkar ve kadınların kararlarda ne ölçüde etkili olduklarını belirlemeye yönelik olarak iki ifadeye verilen yanıtların dağılımlarını vermektedir. Buna göre, katılımcıların \%54’ten fazlası "her kesimden insanın görüş ve düşüncelerine başvuruldu" ifadesine kesinlikle katılmadıkları ya da katılmadıklarını belirtirken, sadece \%27,9'u olumlu bir yanıt vermektedir. "Erkekler kadar kadınların da görüşlerine başvuruldu" ifadesine ise \%73,5'i olumsuz görüş bildirirken, sadece \%17'si bu görüşü paylaşmaktadır. Bulgular açıkça katılım sürecinin belirli kesimler ve erkeklere açık olduğunu ve topluluğun çoğunluğunu meydana getiren diğer kesimleri ve özellikle de toplumun yarısına denk gelen kadınları dışladığını göstermektedir.

Tablo 9. Katılımın Niteliği Sorularına Verilen Yanıtların Seçeneklerine Göre Dağılımı

\begin{tabular}{|l|c|c|c|c}
\hline & \multicolumn{2}{|c|}{$\begin{array}{c}\text { Her Kesimden Ínsanın Görüş ve } \\
\text { Düșüncelerine Başvuruldu }\end{array}$} & \multicolumn{2}{c}{$\begin{array}{c}\text { Erkekler Kadar Kadınların da } \\
\text { Görüșleri Alındı }\end{array}$} \\
\cline { 2 - 5 } & $n$ & $\%$ & $n$ & $\%$ \\
\hline Kesinlikle Katılmıyorum & 39 & 26,5 & 66 & 44,9 \\
\hline Katılmıyorum & 41 & 27,9 & 42 & 28,6 \\
\hline Fikrim yok & 26 & 17,7 & 14 & 9,5 \\
\hline Katıliyorum & 32 & 21,8 & 20 & 13,6 \\
\hline Kesinlikle Kat1liyorum & 9 & 6,1 & 5 & 3,4 \\
\hline \multicolumn{1}{c|}{ Toplam } & $\mathbf{1 4 7}$ & $\mathbf{1 0 0 , 0}$ & $\mathbf{1 4 7}$ & $\mathbf{1 0 0 , 0}$ \\
\hline
\end{tabular}

Tablo 10 proje sonuçlarının, hanehalkı reislerince ne ölçüde tasvip edildiğini gösteren iki ifadeye verilen yanıtları göstermektedir. Bunlardan ilki olan "proje kapsamındaki çalışmaların çoğunu tasvip ediyorum” görüşüne katılımcıların \%43'ten fazlasının olumsuz, \%19,3'ünün fikrinin olmadığı ve geriye kalan \%37,3'ünün ise olumlu yanıt verdiği görülüyor. "Halk genelde projenin sonuçlarından memnun kaldı” şeklindeki ifadeye karşılık katılımcıların \%26,4'ünün olumsuz, \%21'nin ne olumlu ne de olumsuz ve \%42,7'sinin ise olumlu bir görüş bildirdiği görülmüştür. 
Tablo 10. Proje Sonuçlarının Benimsenme Düzeyine İlişkin Sorulara Verilen Yanıtların Dă̆ılımı

\begin{tabular}{l|c|c|c|c}
\hline \multirow{2}{*}{} & \multicolumn{2}{|c|}{$\begin{array}{c}\text { Proje Kapsamındaki Çalışmaların } \\
\text { Çoğunu Tasvip Ediyorum }\end{array}$} & \multicolumn{2}{c}{$\begin{array}{c}\text { Halk Genelde Projenin } \\
\text { Sonuçlarından Memnun Kaldı }\end{array}$} \\
\cline { 2 - 5 } & $n$ & $\%$ & $n$ & $\%$ \\
\hline Kesinlikle Katılmıyorum) & 19 & 13,1 & 14 & 9,8 \\
\hline Katılmıyorum & 44 & 30,3 & 38 & 26,6 \\
\hline Fikrim yok & 28 & 19,3 & 30 & 21,0 \\
\hline Katıliyorum & 41 & 28,3 & 45 & 31,5 \\
\hline Kesinlikle Katıliyorum & 13 & 9,0 & 16 & 11,2 \\
\hline \multicolumn{1}{c|}{ Toplam } & $\mathbf{1 4 5}$ & $\mathbf{1 0 0 , 0}$ & $\mathbf{1 4 3}$ & $\mathbf{1 0 0 , 0}$ \\
\hline \multicolumn{2}{c}{}
\end{tabular}

Sonuç olarak katılımın düzeyi ve kapsayıcılığına kıyasla proje faaliyetleri ve ortaya çıkan sonuçları olumlu olarak değerlendirenlerin oranları nispetten yüksek olsa da bu, toplam hane reislerinin \%43'üne bile ulaşamamaktadır. Bu sonuçlar, katılımın niteliğinin de sorgulanması gerektiğini göstermektedir. Söz konusu katılım, kararlar ya da gerçekleştirilen faaliyetlerin belirlenmesi üzerinde etkisi olmayan bir tür bilgilendirme ya da tokenizm olarak değerlendirilmelidir.

\section{Hane Halkı Reislerinin Katılımlarını Etkileyen Sosyoekonomik ve Demografik Özellikler}

Araştırmanın bu kısmında, literatür taramasında da geçen faaliyet türü, bireysel sosyoekonomik ve demografik özelliklerin katılımla olan ilişkileri faktör analizi ve sıralı logit modeli ile değerlendirilmektedir.

Tablo 11. Katılım ve Proje Sonuçlarıla İlgili Yedi İfadenin Temel Bileşenler Analizi (TBA) Sonuçları

\begin{tabular}{|c|c|c|c|}
\hline & & \multicolumn{2}{|c|}{ Component } \\
\hline & & 1 & 2 \\
\hline \multicolumn{2}{|c|}{ Köykentle ilgili çalışmalar yürütülürken, her kesimden insanın düşünce ve görüşlerine başvuruldu } & 859 & \\
\hline \multicolumn{2}{|c|}{ Köykent Projesiyle ilgili çalışmaların yürütülmesinde görüşlerimize başvuruldu } & 844 & \\
\hline \multicolumn{2}{|c|}{ Köykent Projesinin hazırlanması ve planlanmasında görüşlerimize başvuruldu } &, 824 & \\
\hline \multicolumn{2}{|c|}{ Köykentle ilgili çalışma ve kararlarda genelde etkili olduğumu düşünüyorum } & ,664 & \\
\hline \multicolumn{2}{|c|}{ Köykent Projesinin uygulamasında en az erkekler kadar köydeki kadınlarında görüşleri alındı } & 610 & \\
\hline \multicolumn{2}{|l|}{ Halk genelde Köykent Projesinin sonuçlarından memnun kaldı } & & ,878 \\
\hline \multicolumn{2}{|l|}{ Proje kapsamında yapılan çalışmaların çoğunu tasvip ediyorum } & & ,824 \\
\hline Örneklem yeterliliği için Kaiser-Mayer Olkin (KMO) Testi & 0,798 & & \\
\hline Barlett' in Sphercity Ki-Kare Testi & 399,91 & & \\
\hline Serbestlik derecesi (df) & 21 & & \\
\hline$P$ değeri & 0,000 & & \\
\hline
\end{tabular}

$\mathrm{Bu}$ amaçla öncelikle faktör analizi yoluyla katılımın ve proje sonuçlarının etkinliklerinin göstergeleri olarak gözlemlenen değişkenlere neden olan faktörler belirlenmekte, daha sonra da bu faktörlerden katılıma ilişkin olanın hanehalkı reislerinin sosyoekonomik ve demografik özellikleriyle olan ilişkileri açıklanmaktadır.

Ankette yer alan katılım ve proje sonuçlarına ilişkin yedi sorunun varimax döndürme ile gerçekleştirilen Temel Bileşenler Analizi'nin (TBA) faktör yüklemeleri Tablo 11'de verilmektedir. Sonuçlara göre, 7 ayrı ifadenin KatılımEtkinliği ve ProjeEtkinliği adları altında 
iki faktörden (latent değişken) meydana geldiği anlaşılmıştır. Burada verilmemekle birlikte, iki faktör toplam varyansın \%67’sinden fazlasını açıklamaktadır. Birinci faktör ilk beş ifadeden oluşup, katılımın etkinliğini vurgulamakta ve bu nedenle KatılımEtkinliği adı altında kaydedilmiştir. ProjeEtkinliği adıyla kaydedilen ikinci faktör ise, iki ifadeden meydana gelmekte ve genelde bireylerin proje çerçevesinde gerçekleştirilen faaliyetleri ne ölçüde kabul edilebilir gördüklerini göstermektedir. TBA'nın geçerliliğine ilişkin KMO ve Barlett testleri, TBA'nın sonuçların güvenilir ve geçerli olduklarını göstermektedir. Sonuçlara göre, ilk beş değişken ve sondaki iki değişkenden iki ayrı indeks geliştirmek olanaklıdır. Sıralı logit modelinde kullanılmak üzere önce bu ifadeler için iki ayrı indeks (KatılımIndx ve ProjeIndx) hesaplanmış, ardından da iki kategorik değişkenlere dönüştürülmüştür. İndekslerin hesaplanmasında KatılımIndx $=\left(s_{1}+s_{2}+\cdots+s_{n}\right) / n$ eşitliği kullanılmıştır. Bu eşitlikte $s_{n}$ her bir hanehalkı reisinin katılım ve proje etkinliğine ilişkin ifadelere karşılık seçtikleri "Kesinlikle Katılmıyorum", "Katılmıyorum" ve" Kesinlikle Katılıyorum” gibi seçeneklerin 1'den 5'e kadar değișen skorlarıdır. Bunlar daha sonraki istatistiki analizlerde kullanmak üzere, aritmetik ortalama ve kategorilerin anlamlarında dikkate alınarak tekrar kodlanarak KatılımEtkinliği ve ProjeEtkinliği adlı iki kategorik bir değişkene dönüştürülmüştür.

Tablo 12'ye göre, katılımcıların \%59'dan fazlası proje sürecindeki katılımın düzeyini düşük, \%24,5’i orta ve \%16,3’ü de yüksek olarak değerlendirmektedir.

Tablo 12. Katılım Etkinliğini Düşük, Orta ve Yüksek Düzeylerde Değerlendiren Katılımcıların Yüzdeleri

\begin{tabular}{lccc}
\hline Katılım Düzeyi & Frekans & Yüzde & Birikimsel Yüzde \\
\hline Düşük & 87 & 59,2 & 59,2 \\
Orta & 36 & 24,5 & 83,7 \\
Yüksek & 24 & 16,3 & 100,0 \\
Toplam & 147 & 100,0 & \\
\hline
\end{tabular}

Tablo 13 ise ProjeEtkinliği değişkeninin farklı seviyelerinin dağılımlarını göstermektedir. Bu değişkenin "Yüksek" kategorisinin bulunmaması dikkat çekmektedir. Bunun nedeni değişkenin elde edildiği indeksin aldığı değerlerin oldukça düşük olmasıdır. Dolayısıyla da "Yüksek Katılım” düzeyinin çıkarılmasına ve "Düşük" düzey kategorisinin de "Oldukça Düşük" ve "Düşük" biçiminde iki kategoriye ayrılmasına karar verilmiştir. Buna göre, katılımcıların \%69,5'inin proje kapsamında gerçekleştirilen faaliyetleri ve sonuçlarını benimsemediklerini söyleyebiliriz.

Tablo 13. Proje Etkinliğini Oldukça Düşük, Düşük ve Orta Düzeyde Değerlendiren Katılımcıların Yüzdeleri

\begin{tabular}{lccc}
\hline Proje Etkinlik Düzeyi & Frekans & Yüzde & Birikimsel Yüzde \\
\hline Oldukça Düşük & 60 & 42,6 & 42,6 \\
Düşük & 38 & 27,0 & 69,5 \\
Orta & 43 & 30,5 & 100,0 \\
Toplam & 141 & 100,0 & \\
\hline
\end{tabular}


$\mathrm{Bu}$ sonuç, proje alanında yaşayan hanehalkı reislerinin proje kapsamında gerçekleştirilen etkinliklerin nitelikleri, gerçekleştirme şekilleri ya da bunların sonuçlarından tatmin olmadıklarını göstermektedir.

KatılımIndx ile ProjeIndx değişkenleri arasında 0.413 gibi güçlü ve anlamlı pozitif bir korelasyon bulunmaktadır $(n=147, p<: 0,01)$. Buna göre, katılımım düzeyi artıkça, proje sonuçlarının benimsenme düzeyi de artmaktadır. Bu bulgu, katılım yoluyla yerel sorunları daha iyi tanıma fırsatı elde eden ve çözümlerine ilişkin tartışmalarda yer alan kişilerin proje sonuçları konusunda da daha gerçekçi beklentiler oluşturduklarını göstermektedir.

Tablo 14 bağımlı değişkenin KatılımEtkinliği olduğu Sıralı Logit modelinde yer alan tüm değişkenlerin betimleyici istatistiklerini vermektedir. Burada belirtilmesi gereken, üç düzeyi bulunan bağımlı değişken, yaş ve gelir dışındaki tüm değişkenlerin 1 ya da 0 şeklinde iki değer aldıklarıdır (Bkz. Tablo 2).

Tablo 14. Sıralı Logit Modelinde Kullanılan Değişkenlere İlişkin Betimleyici Ístatistikler

\begin{tabular}{llllll}
\hline & $\mathbf{N}$ & Mini. & Mak. & Art. Ort. & St. Hata \\
\hline KatılımEtkinliği & 147 & 1,00 & 5,00 & 2,3524 &, 99570 \\
Erkek & 149 &, 00 & 1,00 &, 8322 &, 37494 \\
Yaş & 145 & 3,22 & 4,39 & 4,0351 &, 24111 \\
Okul & 149 & 1 & 2 & 1,77 &, 425 \\
Gelir & 139 &, 69 & 9,21 & 6,3107 &, 89255 \\
Köydeyaşam & 83 &, 00 & 1,00 &, 4940 &, 50300 \\
Kooperatif & 143 & 1 & 2 & 1,09 &, 288 \\
Tarım & 149 & 1 & 2 & 1,27 &, 445 \\
Hayvancllk & 149 & 1 & 2 & 1,36 &, 480 \\
Çavdar & 149 &, 00 & 1,00 &, 6107 &, 48923 \\
Toprak & 141 & 1 & 2 & 1,78 &, 416 \\
\hline
\end{tabular}

Bağımlı değişkeninin KatılımEtkinliği olduğu sıralı logit modelin Uyum İyiliği Göstergeleri ve Paralel Doğrular Testi ile analiz sonuçları sırasıyla Tablo 15 ve Tablo 16' da verilmektedir.

Tablo 15. Modelin Uyum İyiliği Göstergeleri ve Paralel Doğrular Testinin Sonuçları

\begin{tabular}{lllll}
\hline Model & $\mathbf{- 2 ~ L o g ~ L i k e l i h o o d ~}$ & Ki-Kare & sd. & p \\
\hline Sadece Sabit: & 230,407 & & & \\
Final: & 206,99 & 23,419 & 10,09 & 0,009 \\
McFadden R ${ }^{2}$ & 0.10 & & & \\
Paralel Doğ. Tes. & & 7.8 & 10 & 0.7 \\
\hline
\end{tabular}

Regresyon sonuçlarına geçmeden önce modelin geçerliliği ve niteliğinden bahsetmek yararlı olacaktır. Paralel Doğru Testi (Parallel Line Test) sıralı logit modelin geçerliliğinin testi açısından önemli olup tahmin edilen katsayıların (Location) bütün kategoriler için aynı olduğu hipotezine dayanır. Bu hipotezin reddedilmesi durumunda sıralı logit modelinin kullanılması uygun olmaz. Nitekim bu hipotez reddedilememektedir. Modelde bazı sorulara yanıt vermeyen katılımcıların çıkarılmasıyla geriye kalan 122 gözlem kullanılmıştır. McFadden R Kare değerine göre, modeldeki bağımsız değişkenler KatılımEtkinliği değişkenindeki varyansın \%10'nu 
açıklamaktadır. Bu tür verilerle yapılan bir araştırma için bu değerin düşük çıkması doğal karşılanmalıdır. Zaten Final modele ait -2 Log Likelihood, Ki-Kare değeri de modelin açıklama gücü taşıdığını göstermektedir. Son olarak eşik değerler ([KatılımEtkinliği =1] ve [KatılımEtkinliği =2]), bağımsız değişkenler 0 olduğunda, bağımlı değişkenlerin değerlerini göstermektedir.

\begin{tabular}{|c|c|c|c|c|c|}
\hline Değişken & $b$ & Std. Hata & Wald & $p$ & Nispi Üstünlük \\
\hline [KatllimEtkinliği $=1]$ & 16,255 & 5,563 & 8,538 &, 003 & \\
\hline [KatllimEtkinliği $=2]$ & 17,549 & 5,595 & 9,838 &, 002 & \\
\hline Toprak &,- 940 & ,491 & 3,672 &, 055 & 0,39 \\
\hline Okul & 1,363 & 623 & 4,790 & 029 & 3,91 \\
\hline Çavdar &,- 506 & ,440 & 1,320 & 251 & 0,60 \\
\hline Kooperatif & 994 & ,625 & 2,531 &, 112 & 2,69 \\
\hline Erkek &,- 183 & ,710 & ,067 & ,796 & 0.83 \\
\hline Köydeyaşam & 763 & ,528 & 2,088 & ,148 & 2.14 \\
\hline Tartm & ,559 & ,583 & ,918 &, 338 & 1.75 \\
\hline Hayvancilık & 149 & ,596 & ,062 & 803 & 1.16 \\
\hline Gelir & 600 & ,322 & 3,477 &, 062 & 1.82 \\
\hline Yaş & 2,752 & 1,125 & 5,985 &, 014 & 15.67 \\
\hline
\end{tabular}

Modele göre, toprak sahibi olmayan katılımcılarla karşılaştırıldığında, toprak sahiplerinin diğer iki düzeye kıyasla yüksek katılım düzeyinde bulunmanın nispi üstünlüğü düşmektedir. Başka bir ifade ile tüm diğer değişkenlerin etkisi sabit tutulduğunda topraksız bir hanehalkı reisinin toprak sahibi olmaya geçişinin, diğer iki katılım düzeyine kıyasla yüksek katılım düzeyinde bulunmasının nispi üstünlüğünü 0.39 kadar azaltmaktadır. Wald Testi’nin 0,055' lik $p$ değeri, sonucun nerede ise 0,05 düzeyinde anlamlı olduğunu göstermektedir. Bu toprak sahipliğinin bu olumsuz etkisi iki gerekçe ile açıklanabilir. Birincisi toprağı bulunmayanlara kıyasla toprak sahipleri ya hayvancılık ya da bitki yetiştiriciliği veya her ikisi ile birlikte uğraşmakta ve dolayısıyla daha yüksek bir fırsat maliyeti ile karşılaşmaktadırlar. Toprağını bir şekilde işleyen kişilerin katılım için daha az zamanı kalır. Tarlayı işletmek kendi başına zaten yorucu bir işken bir de katılım için çaba göstermek daha da fazla yorucu olacaktır. Yine tarla işlerini bırakarak sonucu belirsiz olan katılımla zaman geçirme, işlerin aksaması ve hatta belki de bir yıllık gelirin kaybına yol açabilir. Diğer taraftan, toprağın işletilmesi ve köyde geçirilen süreyi etkilemesi beklenen tarım ve hayvancılık değişkenlerinin istatistiki olarak anlamlı olmasalar da katılımı olumlu etkilemeleri, Toprak değişkeni ile Hayvancılık, Toprak ile Tarım değişkenlerinin etkileşimlerini gösteren yeni değişkenlerin de modele dahil edilmesi gereğini gösteriyor olabilir. Ancak bu çalışmanın sınırlı alanı nedeniyle söz konusu etkileşimler dikkate alınmamaktadır. Son olarak toprak sahiplerinin düşük katılım göstermelerinin diğer bir nedeni de proje faaliyetlerinin kendileri için sınırlı faydalar sağlayacağına inanmaları olabilir.

Diğer tüm değişkenlerin etkileri sabit tutulduğunda, Çavdar köyünden ve erkek olmak toprak sahibi olmada olduğu gibi yüksek bir katılım düzeyinde bulunmanın nispi üstünlügünü düşürmektedir. Ancak bu etki her iki değişken için de istatistiki olarak anlamlı olmadığından, 
daha fazla yorumlanmalarına gereksinim kalmamıştır. Bu sonuçları Tablo 1-8’i birlikte değerlendirdiğimizde genel olarak düşük bir katılım sergilediklerini düşünen katılımcıların cinsiyet ya da geldikleri köyler açısından da benzer bir durum sergilemeleri şaşırtıcı olmamalıdır. Anketlerin dolduruluşu sırasında kadınların bir kısmı, projenin türlü aşamalarına ilişkin kendilerine herhangi bir bilgi verilmediği ya da görüşlerinin sorulmadığını ifade etmişlerdir.

Tablo 16'daki sonuçlara göre, geriye kalan diğer tüm bağımsız değişkenlerin KatılmEtkinliği üzerinde pozitif etkileri bulunmaktadır. Burada da sadece istatistikî olarak anlamlı etkilere sahip değişkenler üzerinde durulacaktır. Modelin sonuçlarına göre, Okul, Kooperatif, Gelir ve Yaş değişkenlerinin anlamlı pozitif etkileri bulunmaktadır. Hiçbir eğitimi olmamaktan en azından ilkokulu bitirmiş olmaya geçiş, diğer katılım düzeylerine kıyasla yüksek katılım düzeyinde bulunmayı olumlu etkilemektedir. Bu niteliğe sahip hanehalkı reislerinin yüksek katılım düzeyinde bulunmalarının diğer katılım düzeylerine olan nispi üstünlüğü hiçbir formel eğitime sahip olmayanlara kıyasla yaklaşık olarak 3,9 kat daha fazladır. Eğitim, yerel topluluk üyelerinin kendi sorunları ve bunların çözümlerine ilişkin girişimlerle daha fazla ilgilenmelerine ve bu konudaki bilincin gelişmesine yol açmaktadır.

Benzer bir şekilde kooperatif üyesi olmak da katılımı olumlu etkilemektedir. Herhangi bir kooperatif üyesi değilken üyeliğe girişin, diğer iki katılım düzeyine kıyasla yüksek katılım düzeyinde bulunmanın nispi üstünlüğü 2,7 kat daha fazladır. Bu değer yaklaşık olarak 0,10 seviyesinde anlamlı bulunmuştur. Konuya ilişkin literatürde de yerel örgütlenmelerde yer alanların bir tür siyasal eğitim ve deneyimi kazandıkları ve katılım gibi topluluğu yakından ilgilendiren konulara karşı hassasiyeti artırdığı belirlenmiştir. Ayrıca örgütlenme içinde bulunan kişilerin, tüm kurallarıyla oyunu, oyunun aktörlerini, aktörler arasındaki ilişkileri ve genel olarak sosyal öğrenmelerine ve deneyim kazanmalarına yol açar. Farklı alanlardaki örgütlenmelerden öğrenilen bilgi ve deneyimler, başka alanlara da kolayca aktarılabilmektedir.

Gelirdeki artış da daha yüksek katılım düzeyinde bulunmanın nispi üstünlügünü artırmaktadır. Sonuçlara göre, gelirde meydana gelen yüzde birlik bir artış, hanehalkı reislerinin yüksek katılım düzeyinin diğer iki katılım düzeylerine olan nispi üstünlüğünü 1,82 kat artırmaktadır. Gelir de kırsal topluluklar için sahip olunan toprak ve hayvan varlığı gibi toplumsal statüyü de belirleyen önemli bir etkendir. Toplumdaki yüksek konumları dolayısıyla varlıklı hanehalkı reislerinin, diğer topluluk üyelerinin beklentilerine karşılık bir tür liderlik sorumluluğu üstlenerek toplumu ilgilendiren sorunlara karşı daha duyarlı davranmalarına ve bu anlamda da daha fazla katılım göstermelerine yol açabilir. Normalde çalışan yüksek gelirliler için katılımın alternatif maliyeti dar gelirlilere kıyasla daha yüksektir ve bu nedenle de daha düşük katılım beklenir. Ancak proje alanında yaşayanların büyük bir kısmı ya emekli olmuş ya da köye tatil amacıyla gelen hanehalkı reislerinden oluştuğu için, böyle bir alternatif maliyetten bahsedilmeyebilir. Üstelik katılımın kendisi, komşularla güzel zaman geçirmek için bir araç olarak da kullanılabilir. Bu çalışmada yer almamakla birlikte, proje kapsamında yapılan faaliyetlerden en fazla hangi kesimlerin yararlandığına ilişkin sorularda bazı katılımcılar bunun “çok açık bir şekilde zenginler olduğu” biçiminde ifadeler kullanmışlardır. Bir algı ya da gerçeği dile getiren bu ve benzeri ifadeler, düşük gelirli kesimlerin katılıma ilişkin beklentilerini ve dolayısıyla katılımlarını olumsuz etkilemiş olabilir. 
Modelin sonuçlarına göre, yaşta meydana gelen yüzde birlik bir artış, düşük ve orta katılım düzeylerine kıyasla yüksek katılım düzeyinde bulunmanın nispi üstünlüğünü 15,67 kat artırmaktadır. Diğer çalışmaların aksine yaş ilerledikçe, katılım düzeyinde bir azalma olamamakta, tam tersine artmaktadır. Proje sınırları içindeki hanehalkı reislerinin \%84 kadarı 45 yaşın üzerindedir. Bu bulgu, emekli ya da emekliğine az bir süre kalmış hanehalkı reislerinin daha genç olanlara kıyasla geri dönüp yerleşmeyi düşündükleri köyleriyle ilgili sorunlara karşı daha duyarlı olduklarını gösterir. Ayrıca, bu kesim arasında İstanbul ve Ankara gibi büyük şehirlere göç etmeyenler de bulunmaktadır. Bunların da benzer bir anlayışa sahip olduklarını varsayabiliriz. Nitekim istatistiki olarak anlamlı olmasa bile yılın en az 6 ayını köyde geçirdiğini gösteren Köydeyaşam değişkeninin de katılımı olumlu etkilediği görülmektedir. Son olarak Tarım ve Hayvancılık değişkenlerinin katılımı olumlu etkiledikleri, ancak istatistiki olarak anlamlı olmadığı görülmektedir.

\section{Sonuç ve Öneriler}

Bulgular, genel olarak Mesudiye Köykent projesinin karar, planlama ve uygulama aşamalarındaki katılımın ancak \%24-26 arasında değişen bir düzeyde kaldığını göstermektedir. Yine katılımın niteliğini belirlemek üzere tüm farklı kesim ve kadınların görüşlerini ne ölçüde kapsadığına ilişkin bulguların "Katılıyorum” ve "Kesinlikle Katılıyorum” yanıtların oranlarının sırasıyla \%17 ve \%27 düzeylerinde kaldığı ve gelir düzeyine bağlı olarak katılımın düzeyinin artığı belirlenmiştir. Proje etkinliği değişkeninde yüksek düzey kategorisinin bulunmaması, Köykent alanındaki proje sonuçlarının yerel toplulukça benimsenmediğini de gösterir. $\mathrm{Bu}$ durumun ortaya çıkmasında katılım ve etkinlik arasındaki korelasyonu göz önüne aldığımızda, kısmen de olsa katılımın yetersiz olmasına bağlanabilir. Proje alanında yaşayan insanların, Köykent benzeri kırsal kalkınma programlarına kendi işgüçleri ve maddi olanaklarıyla destek sağlayacaklarına olan inanç düzeyinin (\%29) çok düşük olması ve komşu köylere kıyasla kendilerinin daha fazla katkı sağlayacaklarını söyleyenlerin sadece \%16 kadar olması da bu durumu göstermektedir. Karşılıklı güven ve genel kabul gören kuralların varlığı sosyal sermayenin önemli unsurlarıdır. Köykent projesi sınırları içinde yaşayan nüfusun sadece \%30 kadarının yıl boyunca sürekli olarak köylerinde kalmaya devam ettiği ve geriye kalanların ortalama 4 ay kadar kalabildikleri belirlenmiştir. Yine bu köylerde yaşayan nüfusun \%80'den fazlasının 45 ya da üstü yaş gruplarında yer almaktadır. Nüfusun bu özellikleri, uzun süre ve ortak yaşam deneyimlerine dayanarak gelişebilen karşılıklı güven ve ortak bir anlayışa engel olmaktadır. Kısacası, bulgular, bu çalışmanın yapıldığı dönemde Köykent proje alanında kalkınmayı teşvik edebilecek sosyal sermayenin oluşumunu engelleyen ciddi demografik, fiziksel ve sosyoekonomik sınırlandırmaların bulunduğunu göstermektedir. Bu bulgular, aynı zamanda resmi proje metinleri ve bazı çalışmalarda iddia edilenin aksine Mesudiye Köykent projesi sürecinde yüksek bir katılımın gerçekleşmediğini, kadınlar ve yoksullar başta olmak üzere her kesimi eşit bir şekilde temsil etmediğini göstermektedir. Özellikle kadınların bir kısmı, kendilerine proje ve ilgili faaliyetleri konusunda bilgi verilmediği ve düşüncelerinin ise hiç başvurulmadığını dile getirmiştlerdir. Yine görüşmeler sırasında projenin sağladığı yarar ve maliyetlerin farklı kesimler ve köyler arsında dağılımına ilişkin olumsuz bir algının olduğu ve bunun "Ankaralılar”, “zenginler”, "muhtarlar”, "toprak sahipleri”, "erkekler” ve "Çavdarlılar” gibi atıflarla vurgulandığı gözlemlenmiştir. Projenin fayda ve maliyetleri, başka bir çalışmanın 
konusu olduğu için burada ele alınmamaktadır. Anca bir gerçek ya da algıdan ibaret bu tür düşüncelerin, proje faaliyetlerine kadın ve dar gelirli gibi bazı dezavantajlı kesimlerin neden daha düşük bir katılım gösterdiklerini kısmen de olsa açıklamaktadır.

Hanehalkı reislerinin sosyoekonomik ve demografik özelliklerinin katılımın düzeyine etkisinin incelendiği sıralı logit modeline göre, yaş, gelir, eğitim ve kooperatif üyesi olmanın katılım üzerinde pozitif ve toprak sahipliğinin de negatif ve istatistiki olarak anlamlı etkileri bulunmaktadır. En az ilkokul mezunu olma, diğer iki düzeye kıyasla yüksek katılımda bulunmanın nispi üstünlüğünü artırmaktadır. Benzer bir şekilde, kooperatif üyesi olma, yaş ve gelirin de katılımı olumlu etkilediği görülmektedir. Kooperatif türü toplumsal örgütlenmelerde yer alma, eğitim ve öğrenim programlarına katılma, sosyal öğrenme ve siyasal deneyime olumlu katkılar sağladığı görülüyor. Bu araştırmanın bulguları da söz konusu unsurların, kırsal kalkınma faaliyetlerine aktif katılım, proje süresince ve sonrasındaki kırsal kalkınma girişimlerinin başarısı ve sürekliliği açısından önemli olduğunu göstermektedir. Ayrıca, sıralı logit modeli, gelir seviyesindeki artışla birlikte katılım düzeyinin de yükseldiğini göstermektedir. Bu da kırsal kalkınma çalışmalarında topluluğun en yoksul kesimlerinin önceden belirlenerek katılımlarını teşvik edecek önlemlerin alınması ihtiyacını göstermektedir. Yine toprak sahiplerinin bundan gelir elde etmek için bir şekilde işletecekleri varsayılabilir. Bu durumda olanlar için tarla işlerinin gecikmesi nedeniyle katılımın alternatif maliyetleri de daha yükselir.

En önemli bulgulardan biri de proje etkinliği ile katılım etkinliği arasında pozitif bir korelasyonun olmasıdır. Başka bir ifade ile katılım düzeyi yükseldikçe, proje sonuçlarının benimsenme düzeyi de yükselmektedir. Bu bulgu, projenin planlama ve uygulama gibi farklı aşamalarına katılımın derecesine bağlı olarak projenin sonuçlarına ilişkin beklentilerin de oluştuğunu, katılım yoluyla sorunlar ve çözümlerin tanımlanmasında rol alanların daha gerçekçi beklentiler içine girdikleri ya da en azından katılımında yer aldıkları proje sonuçlarını veya yapılan faaliyetlerin sorumluluğunu kabul etme eğiliminde olduklarını göstermektedir. $\mathrm{Bu}$ bulgu, katılımın proje çalışmalarının meşruiyetinin sağlanmasındaki kritik bir role ve proje sonrası kırsal kalkınma girişimlerinin sürdürülebilirliğinin sağlanması açısından önemli olduğunu gösterdiği kadar kalkınma programlarının en erken döneminde dikkatle ele alınarak ayrıntılı bir şekilde planlanması ihtiyacını da ortaya çıkarmaktadır. Son olarak bulgular, katılımın tasarım ve planlanması aşamasında başta kadın ve yoksullar olmak üzere farklı yaş grupları, kırsal alandaki geçim kaynakları ve iş yoğunluğu gibi konuların öncelikle ve dikkatlice ele alınarak incelenmesi gerektiğini de göstermektedir.

\section{Kaynakça}

Arnstein, S. R. (1969). A ladder of citizen participation. Journal of the American Institute ofPplanners, 35(4), 216-224.

Aydınlı, H. I.ve Memiş, L. (2014). Sürdürülebilir kentsel kalkınma ve katılım: Mesudiye ilçe kurultayı örneği üzerinde yeniden sorgulamak. Kahramanmaraş Sütçü İmam Üniversitesi İktisadi ve İdari Bilimler Fakültesi Dergisi, 4(1), 65-92. 
Barreteau, O., Bots, P. W. G. ve Daniell, K. A. (2010). A framework for clarifying "participation” in participatory research to prevent its rejection for the wrong reasons. Ecology and Society, 15(2), 1-22.

Bass, S., Dalal-Clayton, B.ve Pretty, J. (1995). Participation in strategies for sustainable development. London: International Institute for Environment and Development.

Başa, Ş. (2000). Ordu ili Mesudiye ilçesi Çavdar ve yöresi köyleri köykent projesi. Türk İdare Dergisi, 429, 117-135

Berber, M., Genç, M. C. ve Yıldız, E. B. (2015). TR90 düzey II bölgesindeki ilçelerin sosyo ekonomik gelişmişlik sıralaması ve sınıflandırılması. Trabzon: Doğu Karadeniz Kalkınma Ajansı (DOKA).

Cankorkmaz, Z. (2011). Türkiye'de bölgesel kalkınma ajansları ve bu ajanslara yönelik eleştiriler. Dokuz Eylül Üniversitesi İktisadi İdari Bilimler Fakültesi Dergisi, 26(1), 113 138.

Chaudhur, S. ve Heller, P. (2003). The plasticity of participation: Evidence from a participatory governance experiment (ESERP Working Paper No: 01-02). New York: Columbia University.

Chhetri, D. P. (2013). People's participation in development. Sikkim in perspective. International Journal of Innovative Research and Development, 2(5), 1476-1497.

Clarıdge, T. (2004). Designing social capital sensitive participation methodologies. Dunedin, New Zeland: Social Capital Research. Erişim adresi: $h t t p: / / w w w . s o c i a l c a p i t a l r e s e a r c h . c o m / w p-$ content/uploads/2013/01/Social-Capital-and-Participation-Theories.pdf

Cooke, B. (2004). Rules of thumb for participatory change agents, S. Hickey ve G. Mohan (Ed.), Participation--from tyranny to transformation? Exploring new approaches to participation in development (s.42-55) içinde. London: Zed Books.

Cooke, B. ve Kothari, U. (2001). The case for participation as Tyrany, B. Cooke and U. Kothari (Ed.), Participation: the new tyranny? (s.1-15) içinde. London: Zed Books.

Cornwall, A. (2000). beneficiary consumer citizen: Perspectives on participation for poverty reduction. Stockholm: Swedish International Development Cooperation Agency.

Cornwall, A. (2008). Unpacking 'Participation'. Models, meanings and practices. Community Development Journal, 43(3), 269-283.

Creswell, J. W. ve Creswell, J. D. (2018). Research design: Qualitative, quantitative, and mixed methods approaches (5. Ed.), Los Angeles: Sage.

Çolakoğlu, E. (2012). Kırsal kalkınma problemine bir çözüm arayışı olarak köy-kent projesi. Uluslararası Yönetim İktisat ve İşletme Dergisi, 3(6), 187-202.

Dawson, C. (2009). Introduction to research methods: A practical guide to anyone undertaking a research project (4. Ed.), Oxford: How To Books Ltd. 
Defrancesco, E., Gatto, P., Runge, F. ve Trestini, S. (2008). Factors affecting farmers' participation in agri-environmental measures: A northern italian perspective. Journal of Agricultural Economics, 59(1),114-131.

Dupraz, P., Vanslembrouck, I., Bonnieux, F. ve van Huylenbroeck, G. (2002, Ağustos). Farmers' Participation in European agri-environmental policies. 10th XEAAE Congress on Exploring Diversity in the European Agri-Food System Kongresinde sunulan bildiri, Zaragoza, Spain. Erişim adresi: https://ageconsearch.umn.edu/record/24799

Erdönmez, C. (2005). Köykent. Olumlu ve olumsuz yönleriyle bir kırsal kalkınma projesinin çözümlenmesi. Turkish Journal of Forestry, A(2), 35-51.

Ertuna, B., Güney, S., Güven, Ö. ve Aydemir, N. (2012). Yerel halkın kırsal turizm gelişimine katılma isteğini etkileyen unsurlar: Kastamonu örneği. Uluslararası Sosyal ve Ekonomik Bilimler Dergisi, 2(2), 59-66.

Fink, A. (1995). How to sample in surveys: The survey kit. Thousand Oaks: SAGE.

Gack, E.E N. (2007). Participatory approaches to development: An analysis of the experiences of development projects in Sudan (Unpublished Ph. D. Thesis), Massey University, Palmerston North, New Zealand.

Glass, J. J. (1979). Citizen participation in planning: The Relationship between objectives and techniques. Journal of the American Planning Association, 45 (2), 180-189.

Gow, D. D. ve Vansant, J. (1983). Beyond the rhetoric of rural development participation: How can it be done?. World Development, 11(5), 427-446.

Güler, Z., Çırakoğlu, D. ve Tokmak, M. (2014). türkiye'de kırsal kalkınma modeli olarak köykent uygulamaları: Bolu Mudurnu ilçesi Taşkesti örneği. Nevşehir Hacı Bektaş Veli Üniversitesi Sosyal Bilimler Enstitüsü Dergisi, 4, 155-167.

Henry, G. T. (1990). Practical sampling. Newbury Park: SAGE.

Güney, R. ve Sat, N. A. (2016). Bölge planlamada katılım: İzmir ve Batı Karadeniz kalkınma ajansları üzerine bir irdeleme. Planlama, 26(2), 101-116.

Işıkçı, Y. M (2018). Türkiye'de kırsal kalkınmada bölge kalkınma ajanslarının rolü. Akademik İncelemeler Dergisi (AID), 13(1), 417-446.

Jones, S. ve Kardan, A. (2013). A framework for analysing participation in development (Report no: 1/2013). Norwegian Agency for Development Corporation (Norad), Oslo: OECD. Erişim adresi: https://www.oecd.org/derec/norway/NORWAY_A_Framework forAnalysingParticipationDevelopment.pdf.

Kaya, T. E. ve Atsan, T. (2013). Kırsal kadının organik tarımı benimsemesini etkileyen faktörler üzerine bir araştırma (TRA1 bölgesi örneği). Atatürk Üniversitesi Ziraat Fakültesi Dergisi, 44(1), 43-49.

Kaynak, O. ve Boz, İ. (2014). Doğu Akdeniz Geçit Kuşağı Tarımsal Araştırma Enstitüsü tarafından geliştirilen bazı pamuk çeşitlerinin benimsenmesi ve yayılması. Bahri Dă̆daş Bitkisel Araştırma Dergisi, 3, 26-34. 
Koç, B. ve Gül, A. (2006). Türkiye'de bir kırsal kalkınma modeli olarak köykentler ve köykentlerde tarımsal işletmelerin sosyal ve ekonomik analizi. Ankara: Tarım ve Köy İşleri Bakanlığı.

Kovanci, S. P. (2005). A critical evaluation of governance in the framework of rural development in Turkey (Unpublished Ph.D. Thesis). Middle East Technical University, Ankara.

La Ferrara, E. (2002). Inequality and group participation: Theory and evidence from rural Tanzania. Journal of Public Economics, 85(2), 235-273.

Leighley, J. E. (1995). Attitudes, opportunities and incentives: A Field essay on political participation. Political Research Quarterly, 48(1), 181-209.

Marın, M. C. (2007). Yerel yönetime katılım aracı olarak planlamanın önemi, H. Özgür ve M. Kösecik (Ed.), Yerel yönetimler üzerine güncel yazılar-II: Uygulama (s. 413-438) içinde. Ankara: Nobel Yayın.

Marın, M. C. (2005). A retrospective view of the Turkish rural urban development policies and the case of the village towns. Urban Policy and Research, 23(4), 497-518.

Matthies, E.ve Krömker, D. (2000). Participatory planning-a heuristic for adjusting interventions to the context. Journal of Environmental Psychology, 20(1), 65-74.

Oakley, P. (1991). The concept of participation in development. Landscape and Urban Planning, 20(1-3), 115-122.

O'faircheallargh, C. (2010). Public participation and environmental impact assessment: Purposes, implications, and lessons for public policy making. Environmental Impact Assessment Review, 30(1), 19-27.

Ohmer, M. L. (2010). How theory and research inform citizen participation in poor communities: The ecological perspective and theories on self-and collective efficacy and sense of community. Journal of Human Behavior in the Social Environment, 20(1), 1-19.

Özer, D. (2004). Kırsal kalkınmada katılımcılık ve katılımcı yayım. HR. Ü. ZF Dergisi, 8(2), 1727.

Rono, P. K. ve Aboud, A. A. (2003). The role of popular participation and community work ethic in rural development: The case of Nandi district, Kenya. Journal of Social Development in Africa, 18 (2), 77-104.

Sonneveld, B.G.J.S. (2002). Formalizing the use of expert jugements for land deregulation assessment: A case stduy for Ethopia, Working Paper WP02-11. Centre for World Food Studies, Amsterdam, the Netherlands.

SPSS Inc., (2008). Released 2008. SPSS statistics for windows, version 17. 0. Chicago: SPSS.

Swapan, M. S. H. (2016). Who participates and who doesn't? Adapting community participation model for developing countries. Cities, 53, 70-77.

Tekeli, İ. (2009). Akılcı planlamadan, bir demokrasi projesi olarak planlamaya. İstanbul: Tarih Vakfi Yurt. 
Tutar, F. ve Demiral, M. (2007). Yerel ekonomilerin yerel aktörleri: Bölgesel kalkınma ajansları. Eskişehir Osmangazi Üniversitesi İİBF Dergisi, 2(1), 65-83.

Wandersman, A.ve Giamartino, G. A. (1980). Community and individual difference characteristics as influences on initial participation. American Journal of Community Psychology, 8(2), 217-228.

White, S. C. (1996). Depoliticising development: The uses and abuses of participation. Development in Practice, 6(1), 6-15.

Wilcox, D. (1994). The guide to effective participation. Brighton: Delta.

Wilson, G. A. (1996). Farmer environmental attitudes and ESA participation. Geoforum, 27, $115-131$.

Wynn, G., Crabtree, B. ve Potts, J. (2001). Modelling farmer entry into environmentally sensitive areas schemes in Scotland. Journal of Agricultural Economics, 52, 65-82.

Yamane, T. (2001). Temel örnekleme yöntemleri. A. Esin, C. Aydın, M. A. Bakır ve E. Gürbüzsel (Çev.), İstanbul: Literatür.

Yıldız, M., Güler, Z. ve Başa, Ş. (2009, Aralık). Türkiye'de kırsal kalkınma politikalarının yönetsel boyutu. Köy-Kent örneği. 11. Ulusal Sosyal Bilimler Kongresinde sunulan bildiri, 9-11 Aralık, Ortadoğu Teknik Üniversitesi, Ankara. Erşim adresi: https://docplayer.biz.tr/160183430-Turkiye-de-kirsal-kalkinma-politikalarininyonetsel-boyutu-koy-kent-ornegi-1.html 